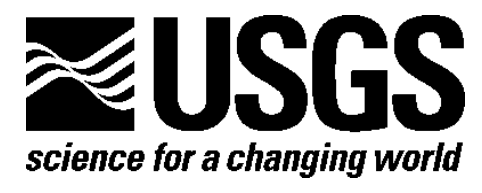

\title{
Seasonal Variability in the Surface Sediments of Mobile Bay, Alabama, Recorded by Geochemistry and Foraminifera, 2009-2010
}

By D.K. Umberger, L.E. Osterman, C.G. Smith, J. Frazier, and K.A. Richwine

Data Series 733

U.S. Department of the Interior

U.S. Geological Survey 


\section{U.S. Department of the Interior \\ KEN SALAZAR, Secretary}

\section{U.S. Geological Survey \\ Marcia K. McNutt, Director}

U.S. Geological Survey, Reston, Virginia: 2012

For more information on the USGS—-the Federal source for science about the Earth,

its natural and living resources, natural hazards, and the environment-visit

http://www.usgs.gov or call 1-888-ASK-USGS

For an overview of USGS information products, including maps, imagery, and publications, visit http://www.usgs.gov/pubprod

To order this and other USGS information products, visit http://store.usgs.gov

Suggested citation:

Umberger, D.K., Osterman, L.E., Smith, C.G., Frazier, J., and Richwine, K.A., 2012, Seasonal variability in the surface sediments of Mobile Bay, Alabama, recorded by geochemistry and foraminifera, 2009-2010: U.S. Geological Survey Data Series 733, 28 p.

Any use of trade, product, or firm names is for descriptive purposes only and does not imply endorsement by the U.S. Government.

Although this report is in the public domain, permission must be secured from the individual copyright owners to reproduce any copyrighted material contained within this report. 


\section{Contents}

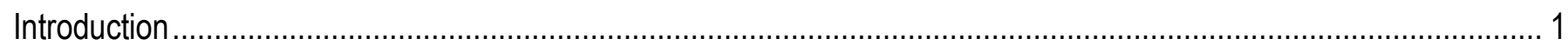

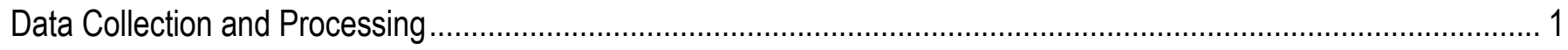

Collection of Surface Samples for Foraminiferal Analyses........................................................................ 1

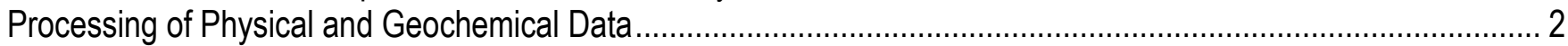

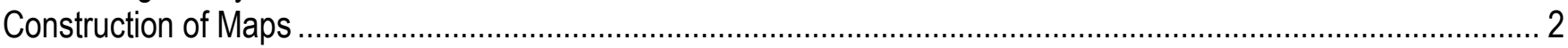

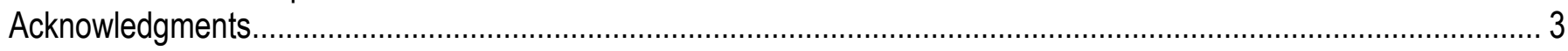

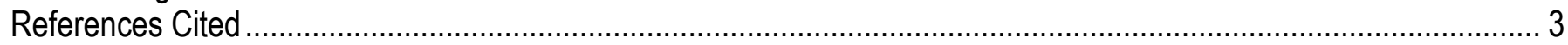

\section{Figures}

1.

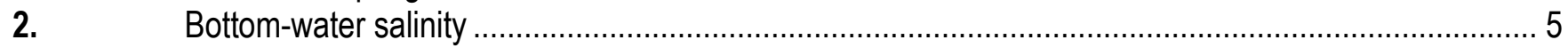

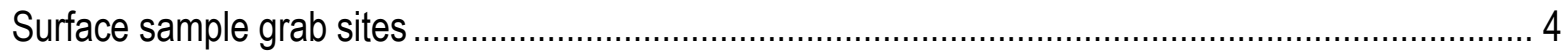

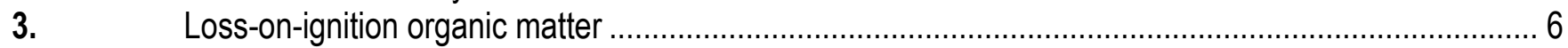

4. Molar total organic carbon to nitrogen ratio ..........................................................................

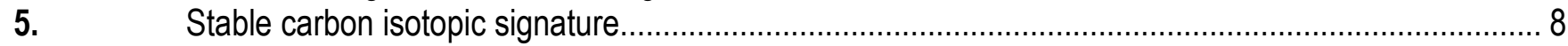

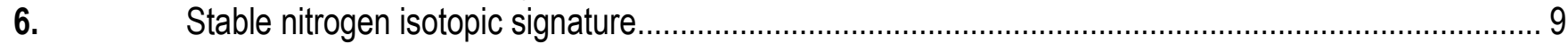

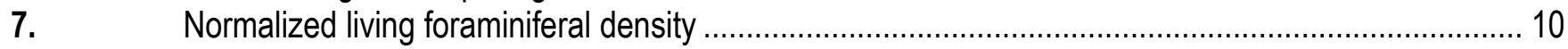

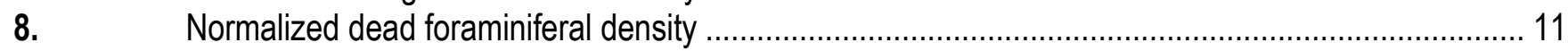

9. Percent dead foraminiferal group September 2009 …............................................................. 12

10. Percent of living foraminiferal groups September 2009 .......................................................... 13

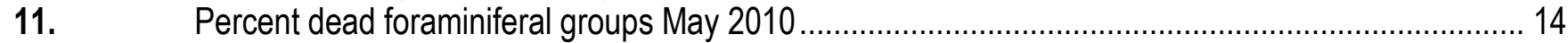

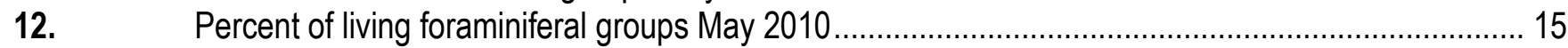

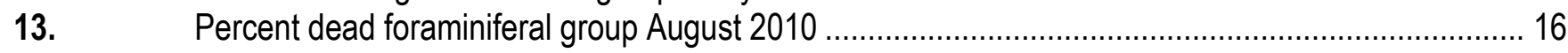

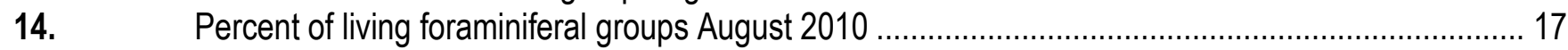

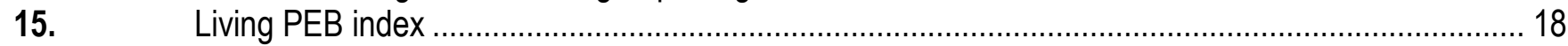

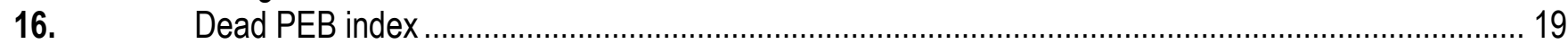

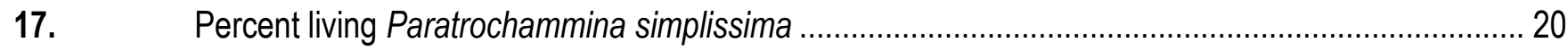

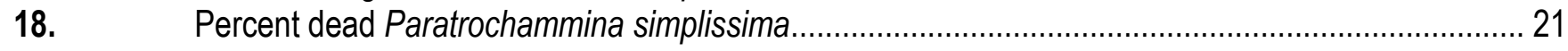

\section{Tables}

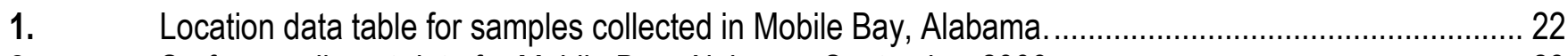

2. Surface sediment data for Mobile Bay, Alabama, September 2009 …............................................... 23

3. Surface sediment data for Mobile Bay, Alabama, May 2010 ............................................................ 24

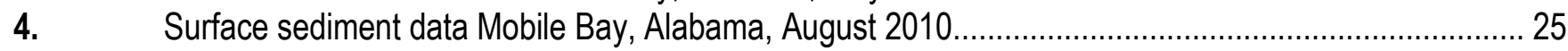




\title{
Seasonal Variability in the Surface Sediments of Mobile Bay, Alabama, Recorded by Geochemistry and Foraminifera, 2009-2010
}

\author{
By D.K. Umberger, L.E. Osterman, C.G. Smith, J. Frazier, and K.A. Richwine
}

\section{Introduction}

A study was undertaken in order to document and quantify recent environmental change in Mobile Bay, Alabama. The study was part of the Northern Gulf of Mexico (NGOM) Ecosystem Change and Hazard Susceptibility project, a regional project funded by the Coastal and Marine Geology Program to understand how natural forcings and anthropogenic modifications influence coastal ecosystems and their susceptibility to coastal hazards. Mobile Bay is a large drowned-river estuary that has been modified significantly by humans to accommodate the Port of Mobile. Examples include repeated dredging of a large shipping channel down the central axis of the bay and construction of a causeway across the head of the bay and at the foot of the bayhead delta. In addition to modifications, the bay is also known to have episodic periods of low oxygen (hypoxia) that result in significant mortality to fish and benthic organisms (May, 1973). For this study a series of surface sediment samples were collected (fig. 1). Surface benthic foraminiferal and bulk geochemical data provide the modern baseline conditions of the bay and can be used as a reference to changing environmental parameters in the past (Osterman and Smith, in press) and into the future. This report archives data collected as part of the Mobile Bay Study that may be used in future environmental change studies.

\section{Data Collection and Processing}

\section{Collection of Surface Samples for Foraminiferal Analyses}

A total of 14 sampling locations (maximum of 13 sites sampled for any one season) were chosen to capture the wide diversity of environments and salinity within the bay (for example, bayhead delta, interior sub-basin, and different marine influence) (fig. 1, table 1). In order to understand seasonal variability in the foraminiferal population, surface sediments were collected with a van Veen grab sampler in September 2009 (11 stations), May 2010 (13 stations), and August 2010 (12 stations) (table 1). Using a spatula, 11 to 35 cubic centimeters $\left(\mathrm{cm}^{3}\right)$ of the topmost surface sediment was collected and placed in two graduated centrifuge tubes (A and B) with a solution of ethanol and Rose Bengal. The sample tubes were shaken several times over the next 24 hours to ensure equal staining of organic tissue (cytoplasm) of the living or recently living foraminifera.

The stained samples were transferred to the U.S. Geological Survey Coastal and Marine Science Center foraminiferal laboratory in St. Petersburg, Fla., and were processed within 6 weeks of collection. The volume of the sediment was recorded using the volume gradation of the tube. The stained sediment samples were washed over a 63-micrometer $(\mu \mathrm{m})$ sieve to remove fine-grained sediment (mud fraction). In some cases a second washing was necessary to disaggregate and remove additional mud fraction. 
The $>63-\mu \mathrm{m}$ fractions were oven dried at $\leq 60{ }^{\circ} \mathrm{C}$, then dry sieved at $125 \mu \mathrm{m}$ (Richwine and Osterman, 2012).

In most cases, the entire $>125-\mu \mathrm{m}$ fraction was spread across a 45 -square, hole-punched tray. Each stained specimen was dropped through a hole in the punched tray onto a stationary 60-square micropaleontological slide placed in a cardboard cutout for later counting and identification. Each sample (up to six at each station) was picked and counted individually.

The dead (non-stained) surface foraminifera were also picked, identified, and counted in a manner similar to the stained samples. Because the dead assemblages were more abundant, these samples were split using a microsplitter to obtain approximately 300 specimens. Complete foraminiferal counts are published (Richwine and Osterman, 2012). All faunal slides will be curated at the National Museum of Natural History, Smithsonian Institution, at the conclusion of the study.

Sample counts of the living and dead benthic foraminifers in each season were tabulated (Richwine and Osterman, 2012). Using that data, the relative abundance of the five most abundant foraminiferal groups in Mobile Bay (Ammotium, Elphidium, Miliolids, Other Agglutinates, All Others) was calculated. Additional calculations were made of the relative contribution of three calcareous foraminiferal species (the PEB index $=\%$ Protononion atlanticum $+\%$ Epistominella vitrea $+\%$ Buliminella morgani) abundant in hypoxic areas of the Gulf of Mexico (Osterman, 2003) to ascertain the extent of hypoxic conditions in Mobile Bay. As the study progressed, we identified that the calcareous foraminiferal assemblage was being subjected to excessive carbonate dissolution (Osterman and Smith, in press). Therefore, we calculated the relative abundance of the agglutinated species Paratrochammina simplissima, whose distribution appeared to be similar to the PEB species.

\section{Processing of Physical and Geochemical Data}

Total Organic matter (TOM), total organic carbon (TOC), total nitrogen (TN), and bulk carbon and nitrogen stable isotopic signatures were measured on surface sediments to characterize the basic organic geochemical framework of Mobile and Bon Secour Bays. All sediment samples were dried at $60{ }^{\circ} \mathrm{C}$ and were homogenized using a mortar and pestle. Percent organic matter in sediments was determined from mass change as a result of combustion (loss-on-ignition). A known mass of dried sediment (approximately 5-10 grams, g) was combusted at $450{ }^{\circ} \mathrm{C}$ for 6 hours. The mass lost during combustion relative to initial sediment mass was used to estimate the fraction (or percentage when multiplied by 100) of organic matter in the sediments. The pooled standard deviation of replicates ( 25 percent of total dataset) was 4 percent. Stable isotopes $\left({ }^{13} \mathrm{C}\right.$ and $\left.{ }^{15} \mathrm{~N}\right)$ and bulk content of organic carbon and total nitrogen $(\mathrm{C}: \mathrm{N})$ were also measured on dried surface samples. Each dried, homogenized sediment sample was preweighed in $5 \times 9$ millimeter $(\mathrm{mm})$ silver capsules (Costech, Inc.) and fumigated with concentrated hydrochloric $(\mathrm{HCl})$ acid for 4 to 6 hours to remove inorganic carbon (Harris and others, 2001). Silver capsules were sealed and analyzed for ${ }^{13} \mathrm{C}$ and ${ }^{15} \mathrm{~N}$ using a PDZ Europa ANCAGSL elemental analyzer interfaced to a PDZ Europa 20-20 Isotope Ratio Mass Spectrometer (Sercon Ltd., Cheshire, U.K.) by the Stable Isotope Facility at the University of California, Davis (http://stableisotopefacility.ucdavis.edu/13cand15n.html). Every third sample was replicated to evaluate sample heterogeneity. Relative standard deviations of $\delta^{13} \mathrm{C}$ and $\delta^{15} \mathrm{~N}$ on replicates (33 percent of total dataset) averaged 0.4 and 4.8 percent, respectively.

\section{Construction of Maps}

The 18 maps (figs. 1 - 18) contained within the report were created at the U.S. Geological Survey Coastal and Marine Science Center in St. Petersburg, Fla. The data (tables 2 - 4) were compiled 
using Microsoft Excel to include all foraminiferal, physical, and geochemical parameters collected. The spreadsheets containing the data were then uploaded into ESRI ArcCatalog, and the maps were built with ESRI ArcMap. Each map contained Mobile Bay bathymetry data obtained from the National Oceanographic and Atmospheric Administration's (NOAA) National Geophysical Data Center (NGDC), which was taken from NOAA's NGDC Web site (http://www.ngdc.noaa.gov/). The individual maps illustrate their respective geochemical / foraminiferal parameter for each sample site location. Details concerning the spatial distribution of the data are described in individual figure captions (figs. 1 - 18).

\section{Acknowledgments}

We thank Chris Reich, Caitlin Reynolds, B.J. Reynolds, and Drew Atchison (USGS - St. Petersburg Coastal and Marine Science Center) for help with sample collection and processing. We also thank the Coastal and Marine Geology Program and the Northern Gulf of Mexico Project for their sustained support during the project.

\section{References Cited}

Harris, David, Horwath, W.R., and van Kessel, Chris, 2001, Acid fumigation of soils to remove carbonates prior to total organic carbon or carbon-13 isotopic analysis: Soil Science Society of America Journal, v. 65, p. 1853-1856.

May, E.B., 1973, Extensive oxygen depletion in Mobile Bay, Alabama: Limnology and Oceanography, v. 18 , no. 3, p. 353-366.

Osterman, L.E., 2003, Benthic foraminifers from the continental shelf and slope of the Gulf of Mexico: an indicator of shelf hypoxia: Estuarine, Coastal and Shelf Science, v. 58, p. 17-35.

Osterman, L.E., and Smith, C.G., in press, Over 100 years of environmental change recorded by foraminifers and sediments in Mobile Bay, Alabama, Gulf of Mexico, USA: Estuarine, Coastal and Shelf Science.

Richwine, K.A., and Osterman L.E., 2012, Benthic foraminiferal census data from Mobile Bay Alabama: counts of surface samples and box cores: U.S. Geological Survey Data Series 704, available at http://pubs.usgs.gov/ds/704/. 


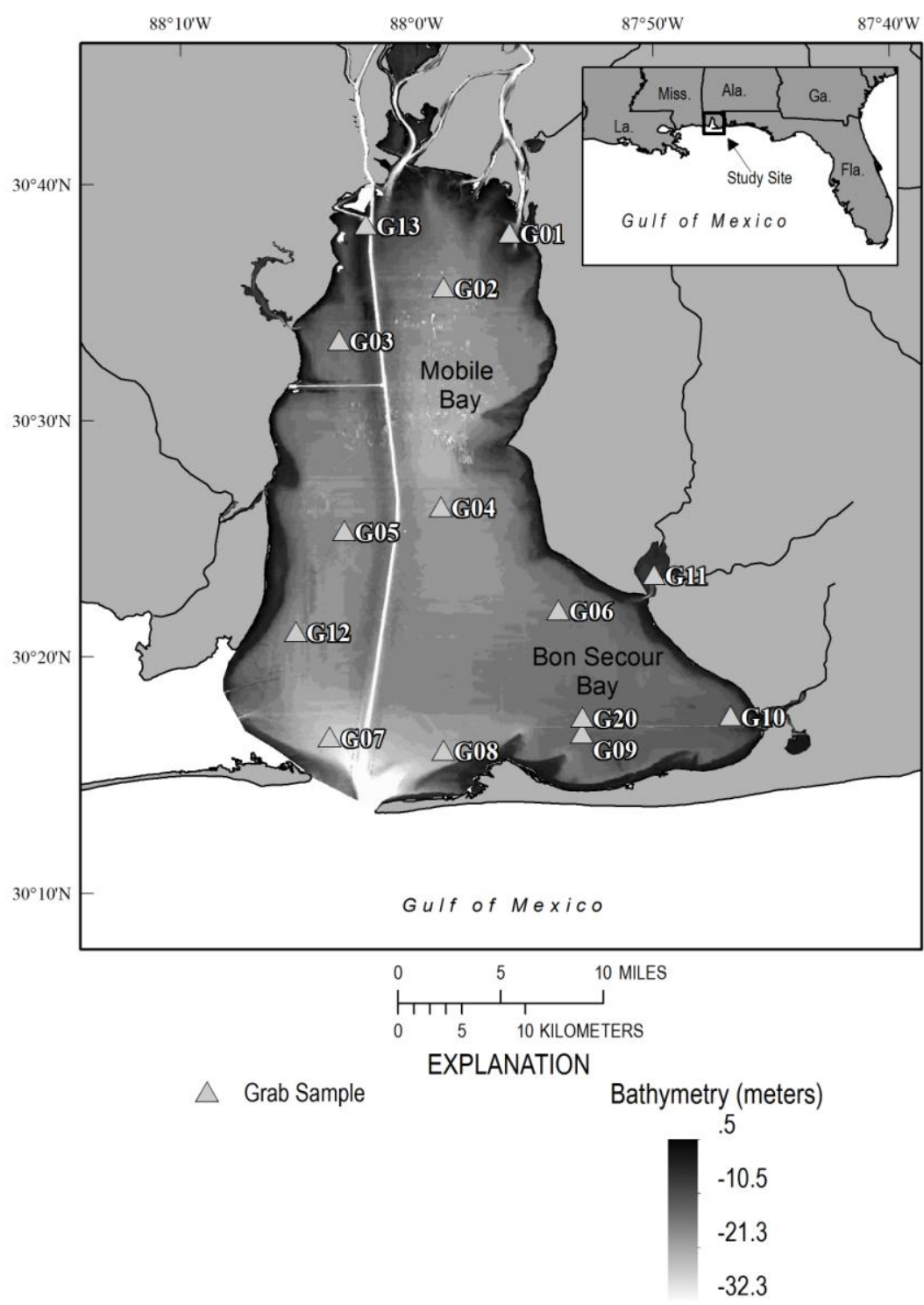

Figure 1. The sampling sites in the Mobile Bay study area. A 2-year (2009 - 2011) study was conducted in Mobile and Bon Secour Bays, located in southeast Alabama, to assess the environmental change over the last 150 years as part of the USGS Northern Gulf of Mexico Ecosystem Change and Hazard Susceptibility project. During the first year of the study, 14 sample sites were visited up to three times (September 29 - October 1 , 2009; May $20-22,2010$; and August 5-7, 2010) to assess seasonal variations in certain geochemical parameters (bottom water salinity and percent organic matter) and benthic foraminiferal assemblages. 


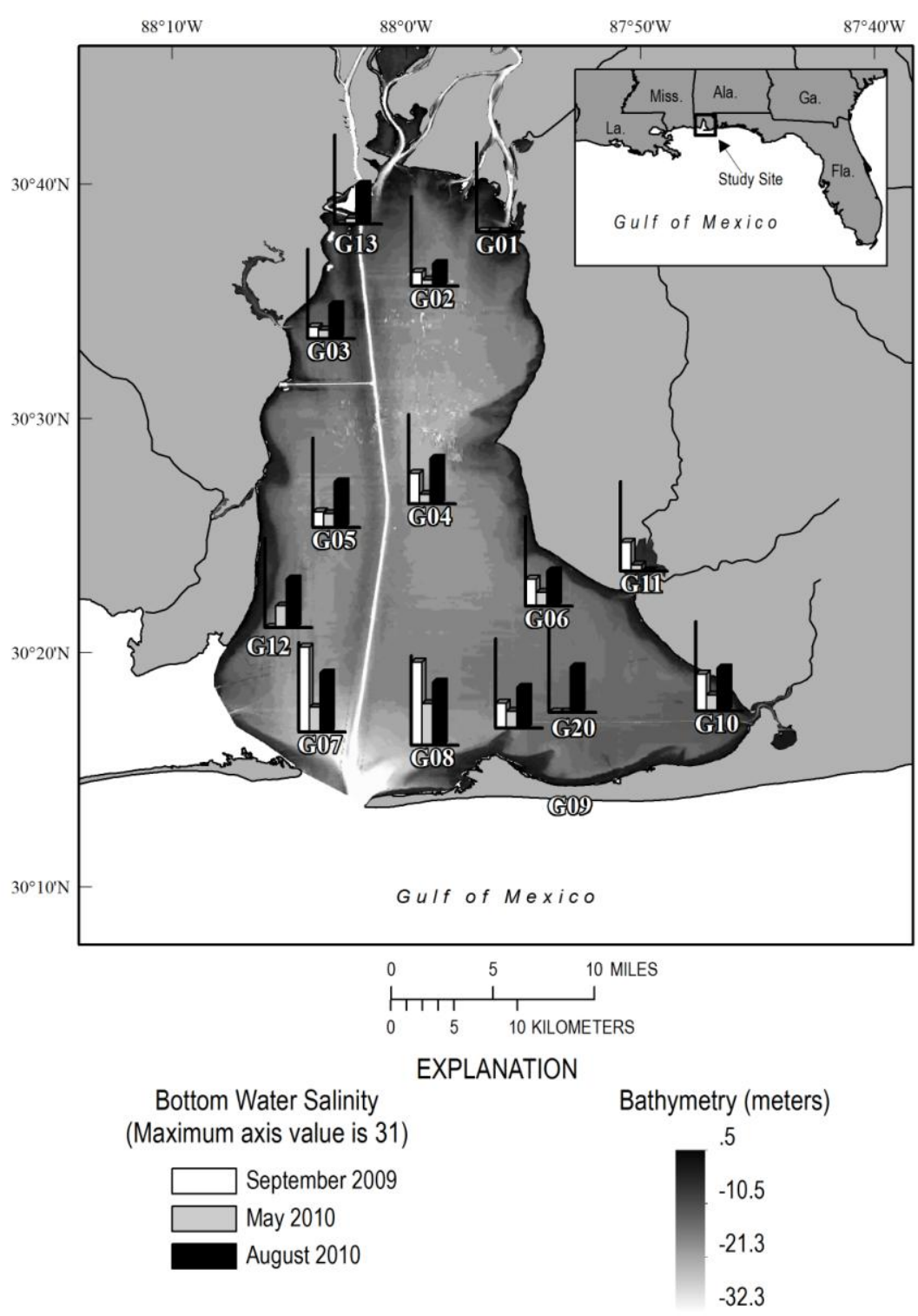

Figure 2. Column graphs showing station salinity for each sampling trip. Bottom water salinity was measured using a multi-probe water quality meter (YSI-556). The columns are color coded to reflect different sampling trips and to capture annual variability. The $y$ axis for each graph is at a maximum salinity of 31 and the origin is 0 . 


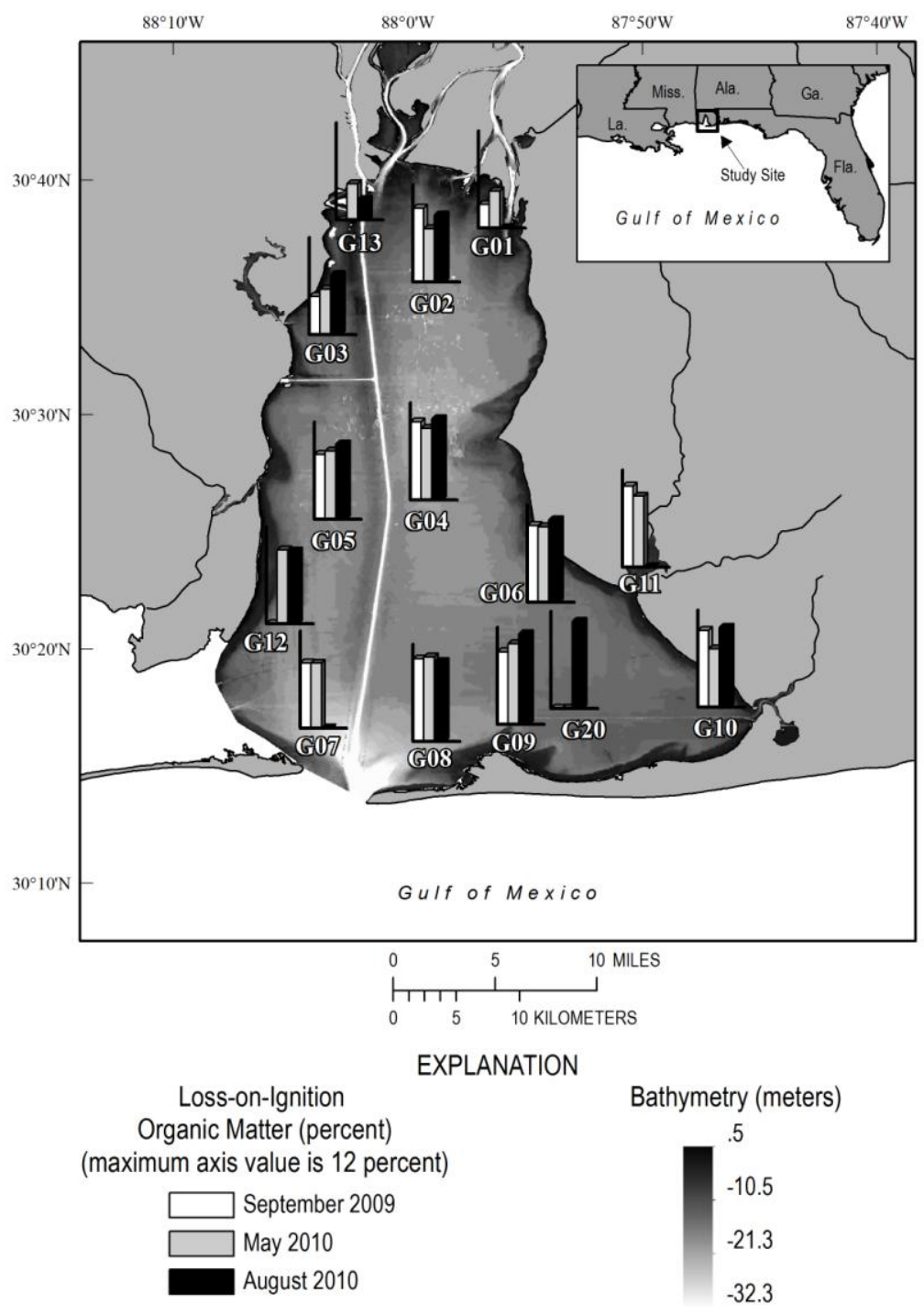

Figure 3. Column graphs showing the relative abundance of organic matter in the surface sediments of Mobile and Bon Secour Bays. During each sampling trip, grab samples were collected and the relative contribution of organic matter was determined by loss during combustion at $450{ }^{\circ} \mathrm{C}$, which is referred to as loss-on-ignition, or LOI on the map. The columns are color coded to reflect different sampling trips and to capture annual variability. The y axis for each graph is at a maximum of 12 percent and the origin is 0 . The pooled standard deviation of replicates ( 25 percent of total dataset) was 4 percent. 


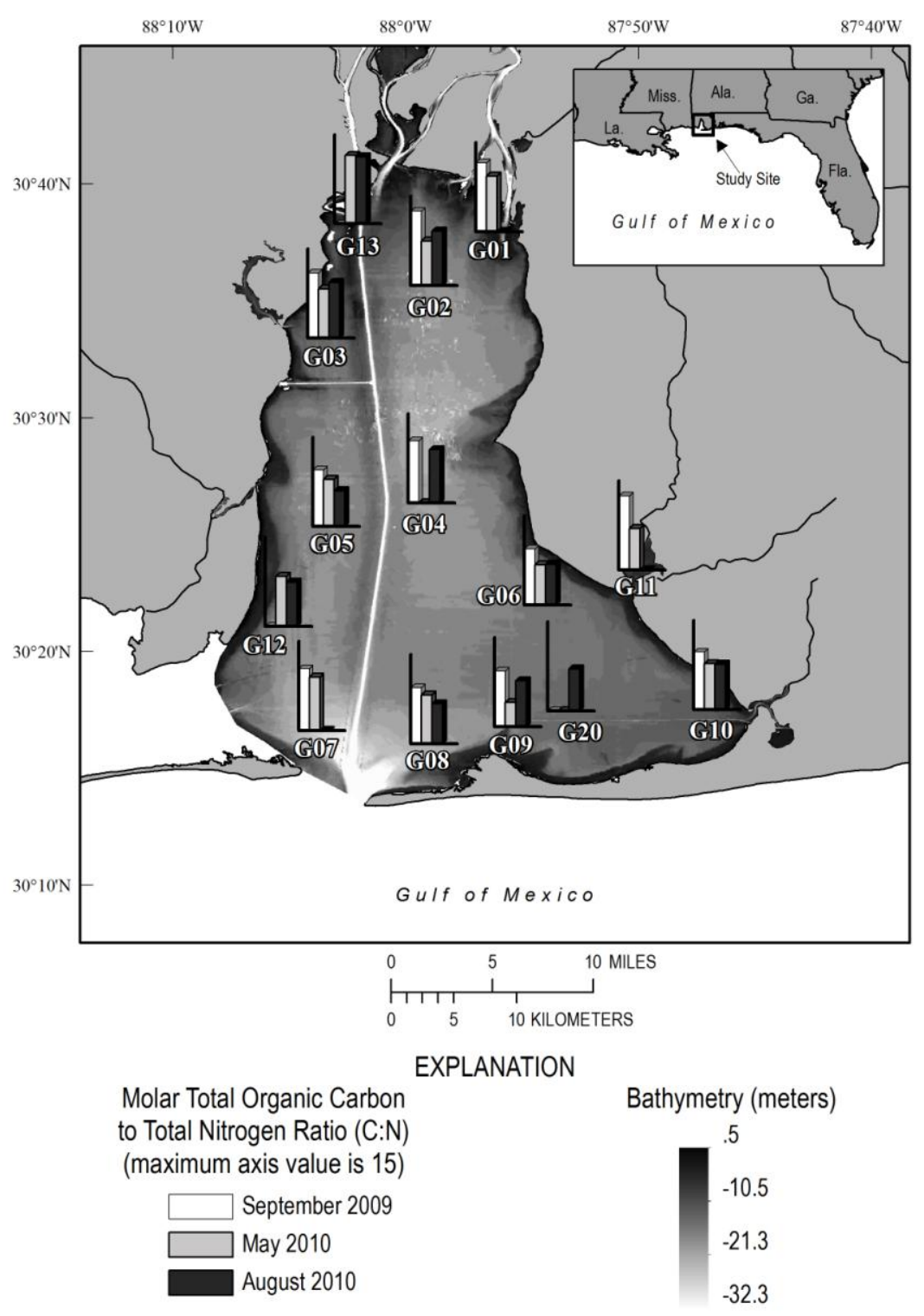

Figure 4. Column graphs showing the molar ratio of total organic carbon to total nitrogen, or C:N. The columns are color coded to reflect different sampling trips and to capture annual variability. The y axis for each graph is at a maximum of 15 and the origin is 0 . 


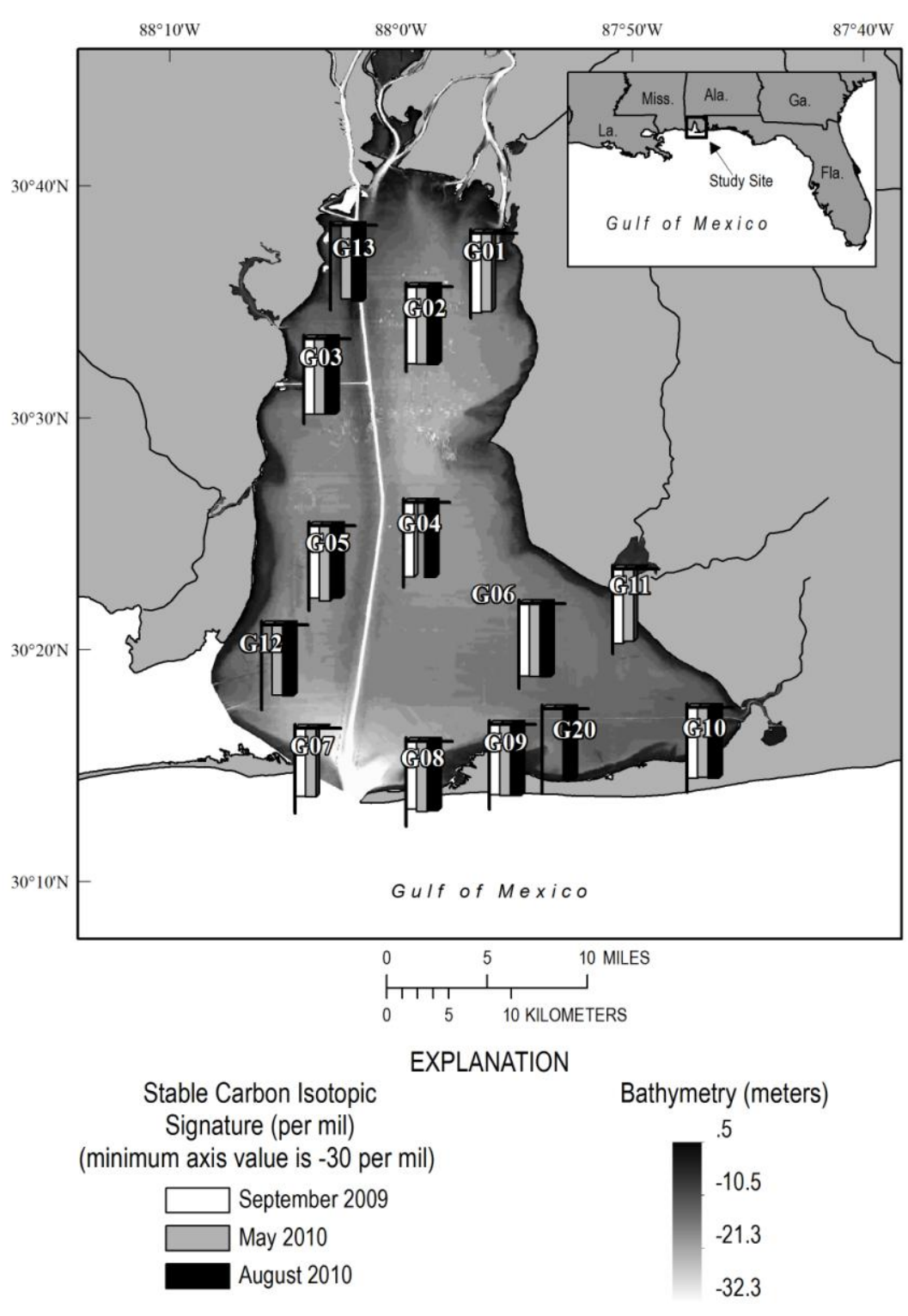

Figure 5. Column graphs showing the stable carbon isotopic signature $\left(\delta^{13} \mathrm{C}\right)$ in per mil $(\%)$. The columns are color coded to reflect different sampling trips and to capture annual variability. The y axis for each graph is at a minimum of $-30 \%$ and the origin is 0 . The pooled standard deviation of replicates (33 percent of total dataset) was 4.8 percent. 


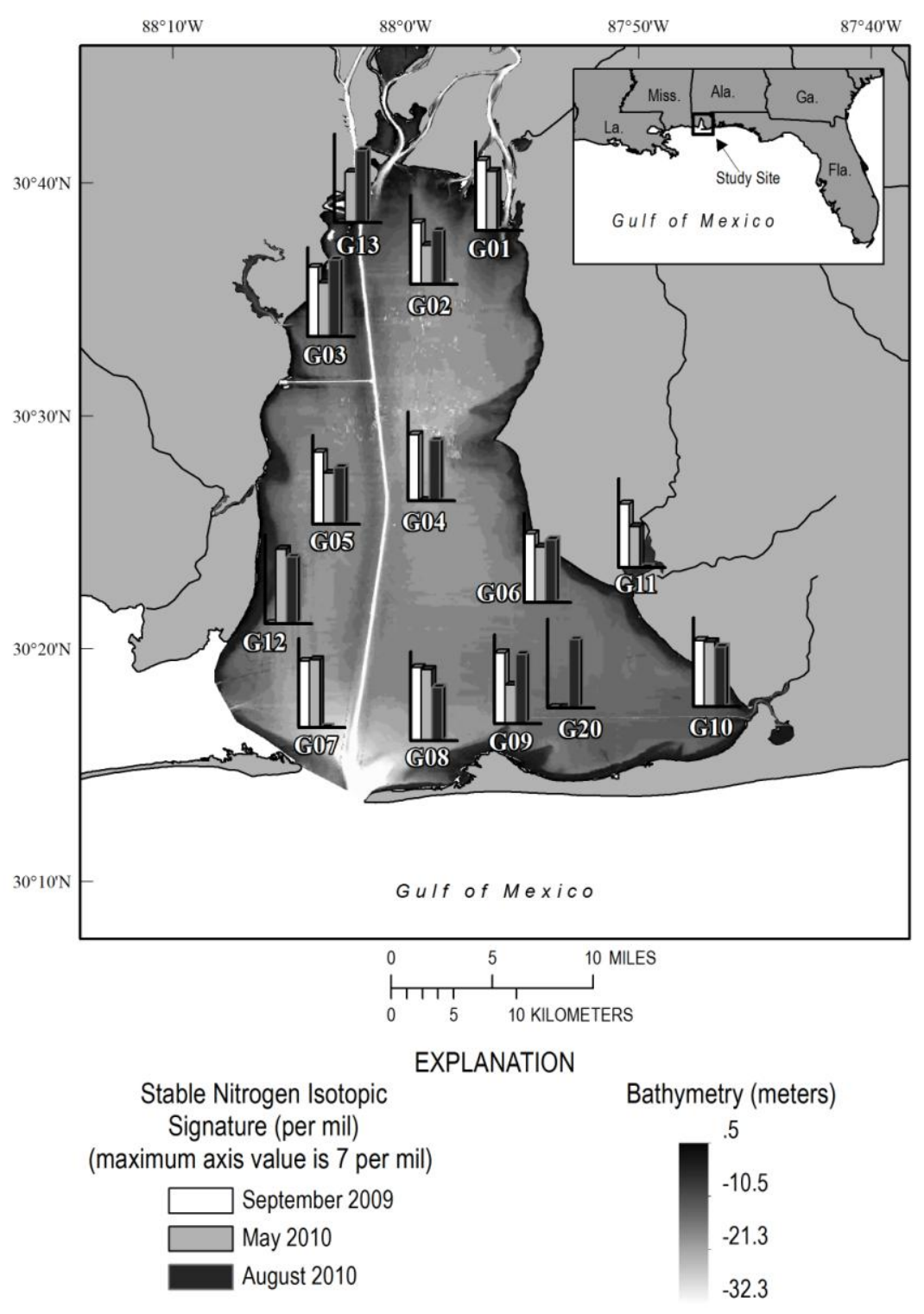

Figure 6. Column graphs showing the stable nitrogen isotopic signature $\left(\delta^{15} \mathrm{~N}\right)$ in per mil $(\%)$. The columns are color coded to reflect different sampling trips and to capture annual variability. The y axis for each graph is at a maximum of $7 \%$ and the origin is 0 . The pooled standard deviation of replicates (33 percent of total dataset) was 0.4 percent. 


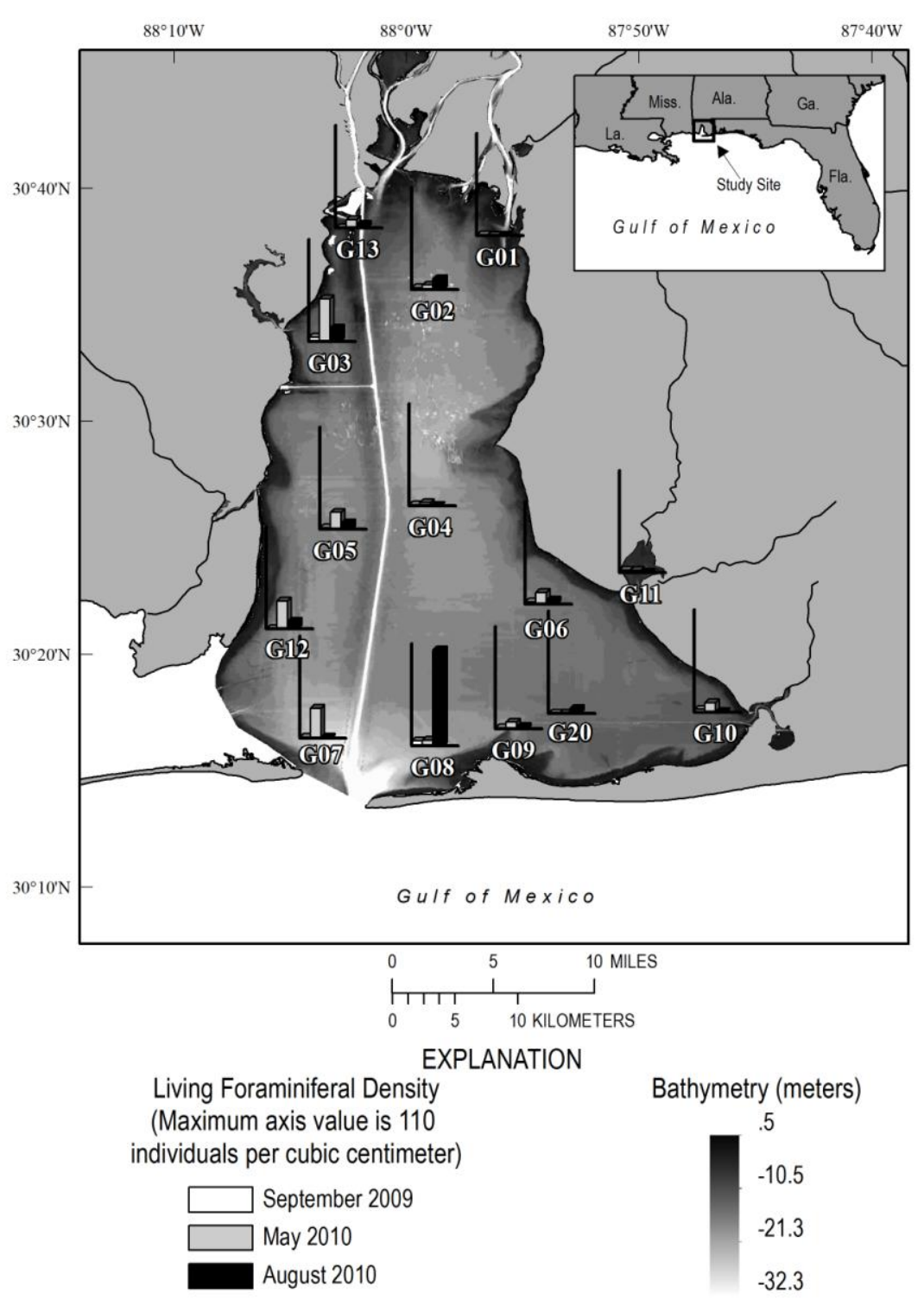

Figure 7. Column graphs showing the density of living foraminifera as determined by the number of specimens stained in 1 cubic centimeter of sediment. Surface sediments were collected and saturated with a Rose Bengal and ethanol mixture to aid in differentiating "living" (stained) and "dead" (unstained) foraminifera. The columns are color coded to reflect different sampling trips and to capture annual variability. Each column defines living density. The y axis for each graph is at a maximum of 110 individuals per cubic centimeter and the origin is 0 . Please note that some sites do not have three measurements (tables 2, 3, and 4). 


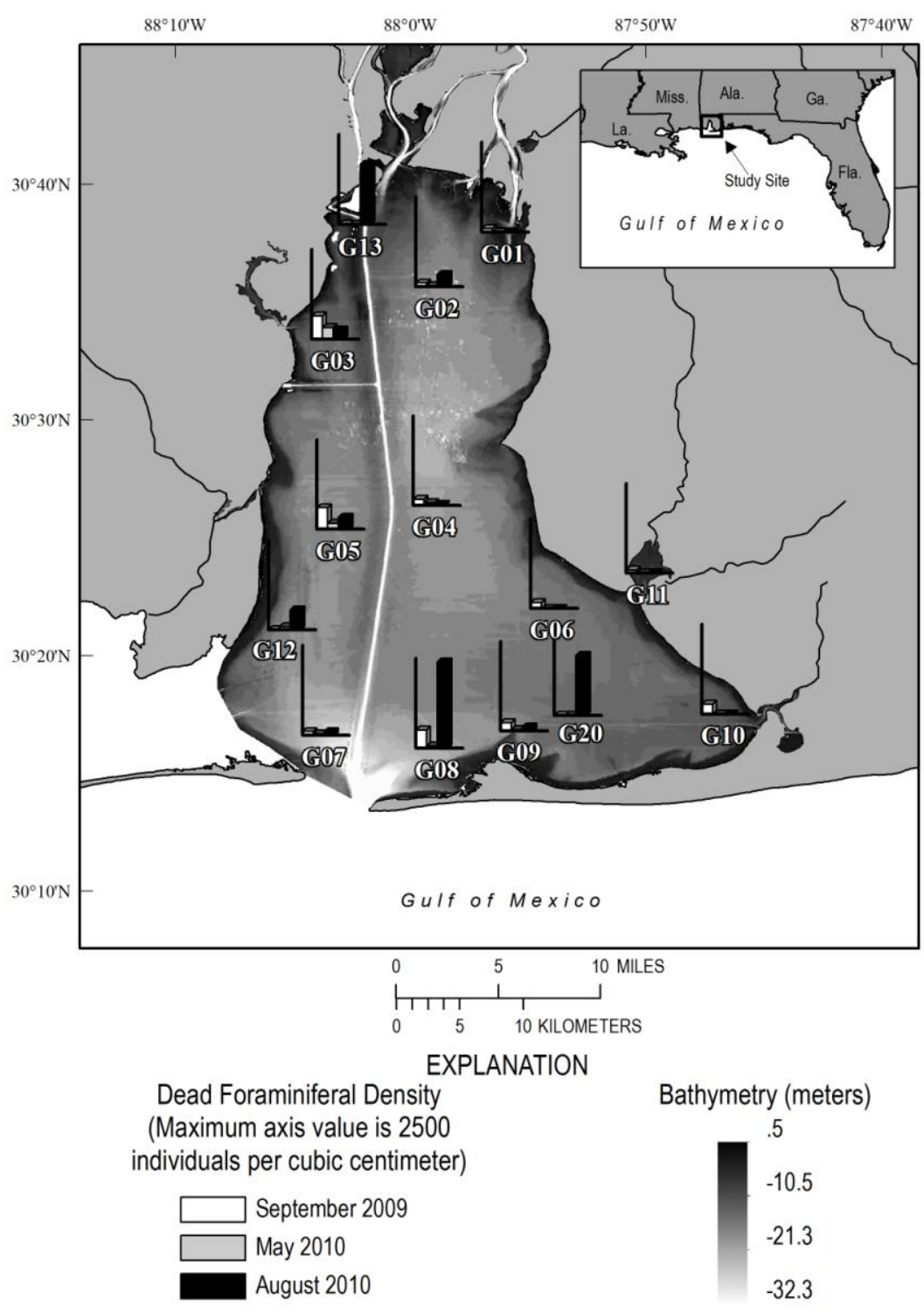

Figure 8. Column graphs showing the density of foraminifera as determined by the number of unstained (dead) specimens in 1 cubic centimeter of sediment. Surface sediments were collected and saturated with a Rose Bengal and ethanol mixture to aid in differentiating "living" (stained) and "dead" (unstained) foraminifera. The columns are color coded to reflect different sampling trips and to capture annual variability. Each column defines density. The y axis for each graph is at a maximum of 2,500 individuals per cubic centimeter and the origin is 0 . Please note that some sites do not have three measurements (tables 2, 3, and 4). 


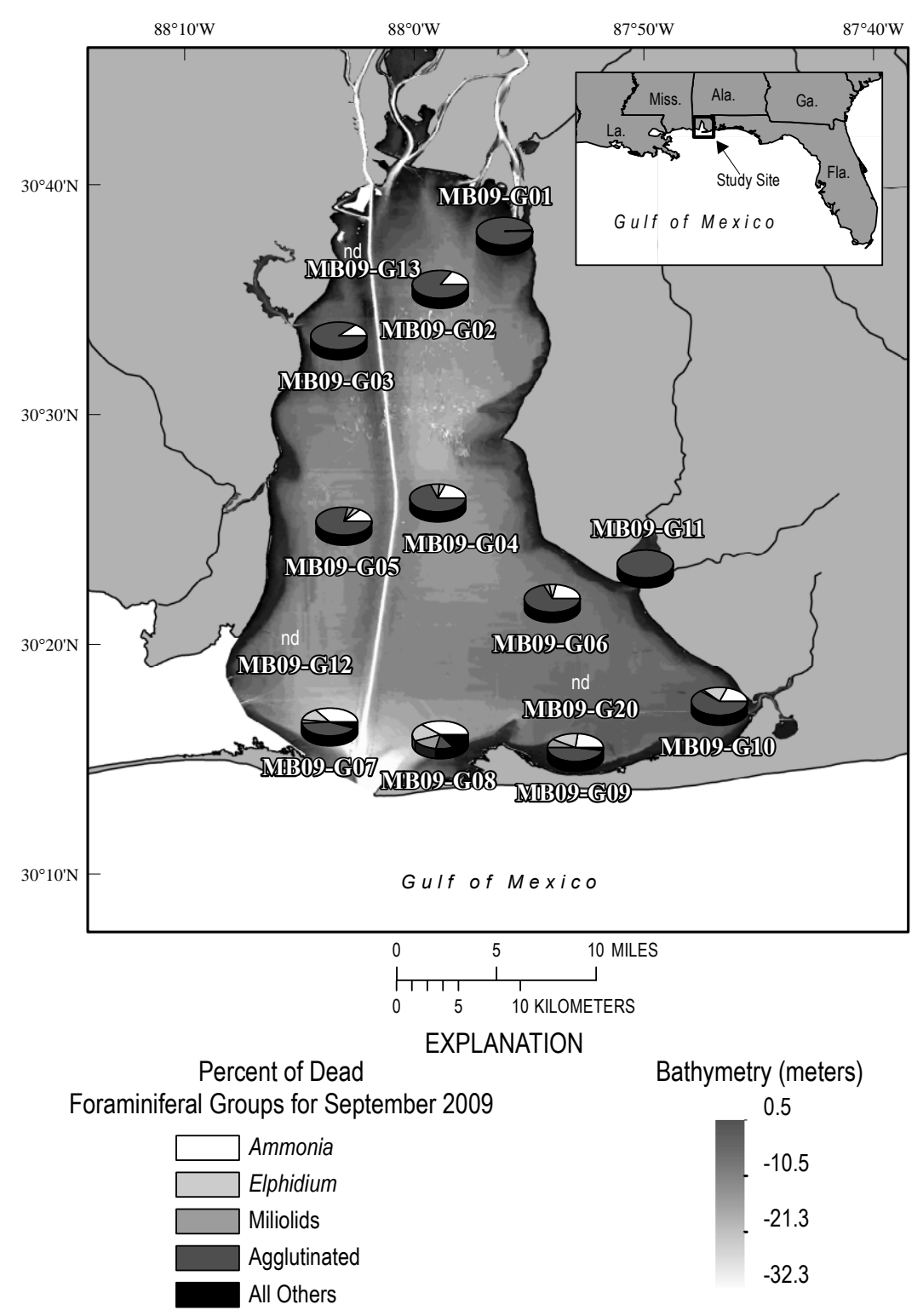

Figure 9. Pie charts showing the relative abundance of dead species (unstained) of each of these groups at 11 sample sites collected September 29 - October 1, 2009 (table 2). Surface sediments were collected and saturated with a Rose Bengal and ethanol mixture to aid in differentiating "living" (stained) and "dead" (unstained) foraminifera. 


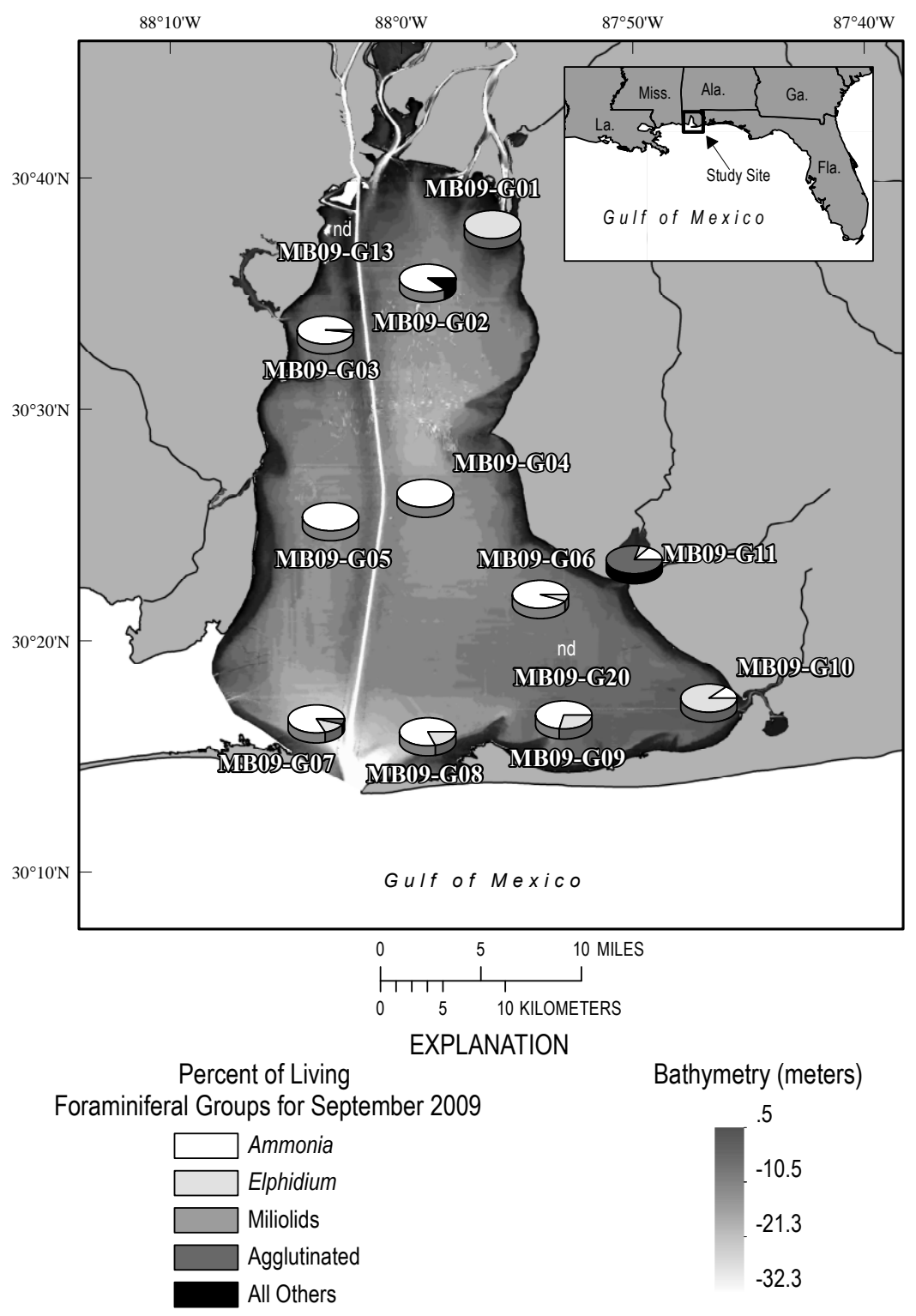

Figure 10. Pie charts showing the relative abundance of living species (stained) of each of these groups at 11 sample sites collected September 29 - October 1, 2009 (table 2). Surface sediments were collected and saturated with a Rose Bengal and ethanol mixture to aid in differentiating "living" (stained) and "dead" (unstained) foraminifera. 


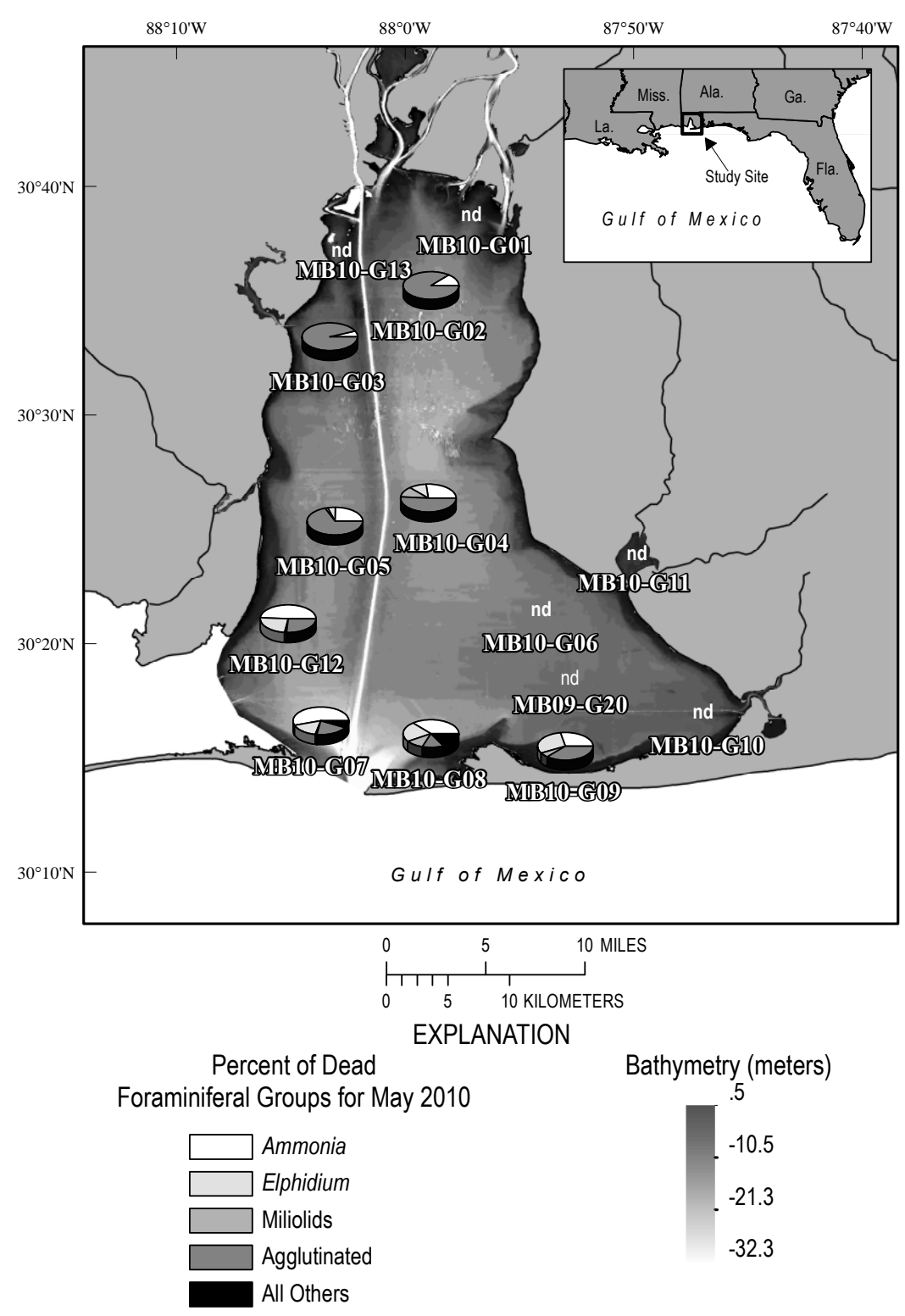

Figure 11. Pie charts showing the relative abundance of dead species (unstained) of each of these groups at eight sample sites collected May 20 -22, 2010 (table 3). Surface sediments were collected and saturated with a Rose Bengal and ethanol mixture to aid in differentiating "living" (stained) and "dead" (unstained) foraminifera. 


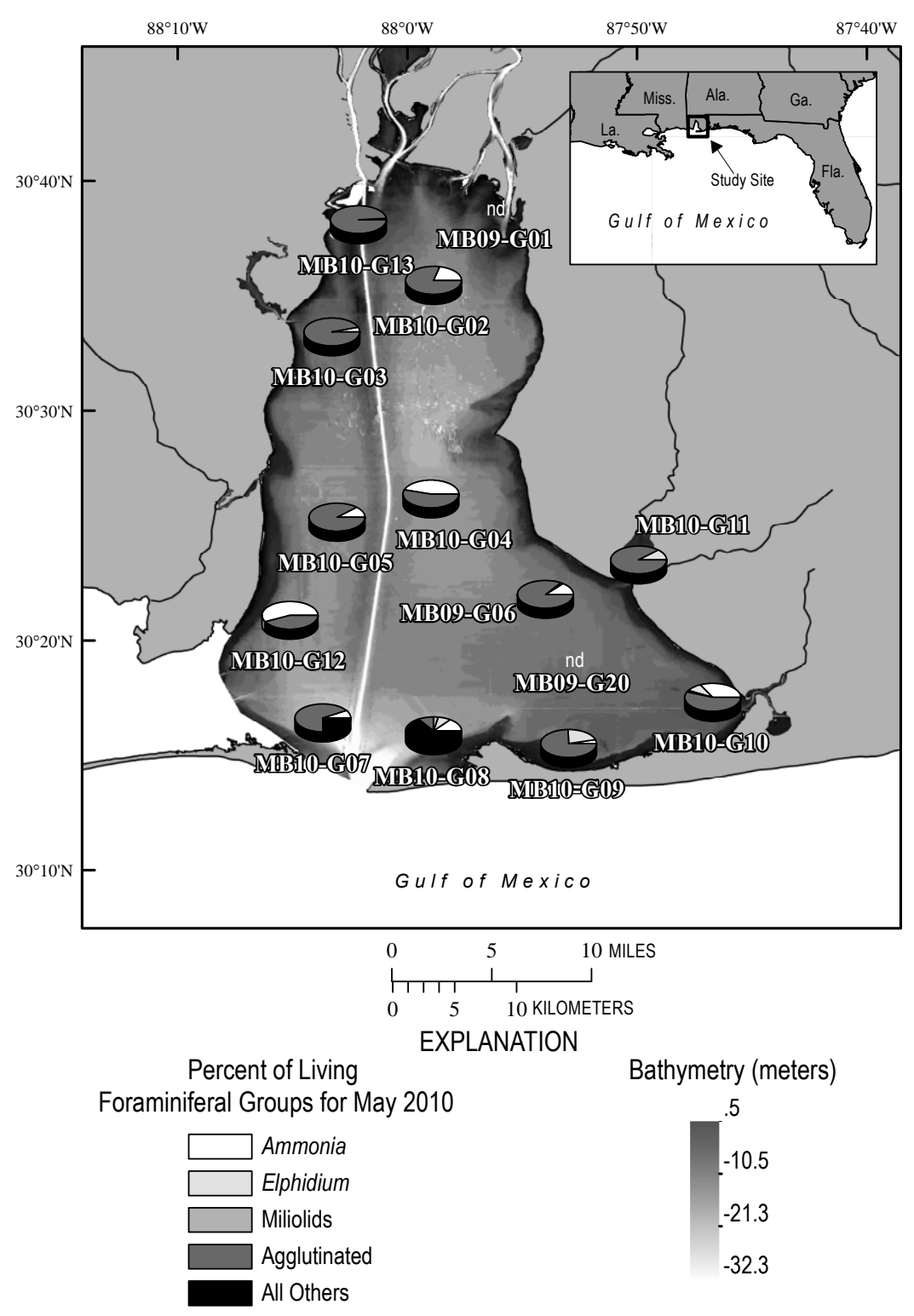

Figure 12. Pie charts showing the relative abundance of living species (stained) of each of these groups at 12 sample sites collected May 20 - 22, 2010 (table 3). Surface sediments were collected and saturated with a Rose Bengal and ethanol mixture to aid in differentiating "living" (stained) and "dead" (unstained) foraminifera. 


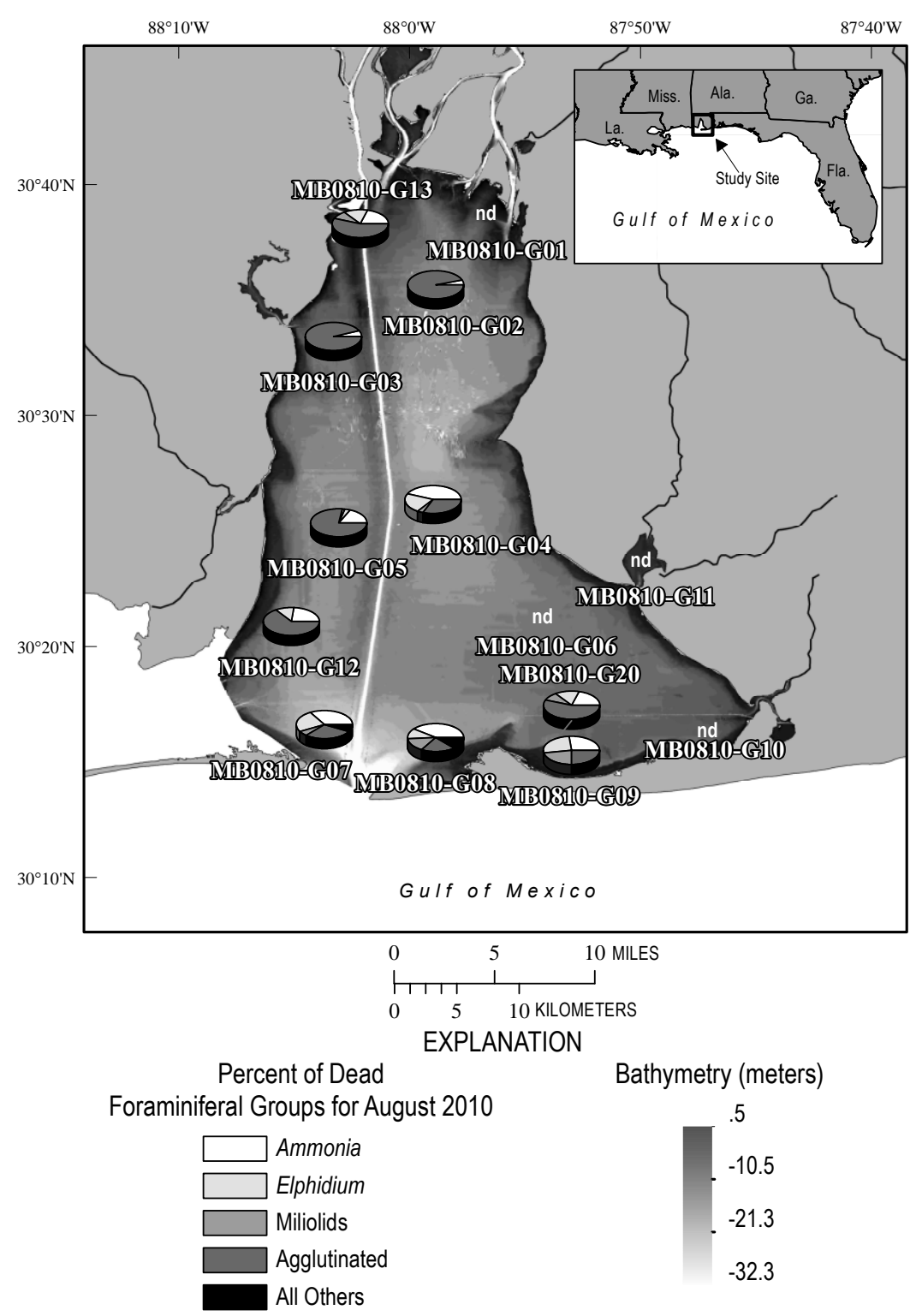

Figure 13. Pie charts showing the relative abundance of dead species (unstained) of each of these groups at 10 sample sites collected August $5-7,2010$ (table 4). Surface sediments were collected and saturated with a Rose Bengal and ethanol mixture to aid in differentiating "living" (stained) and "dead" (unstained) foraminifera. 


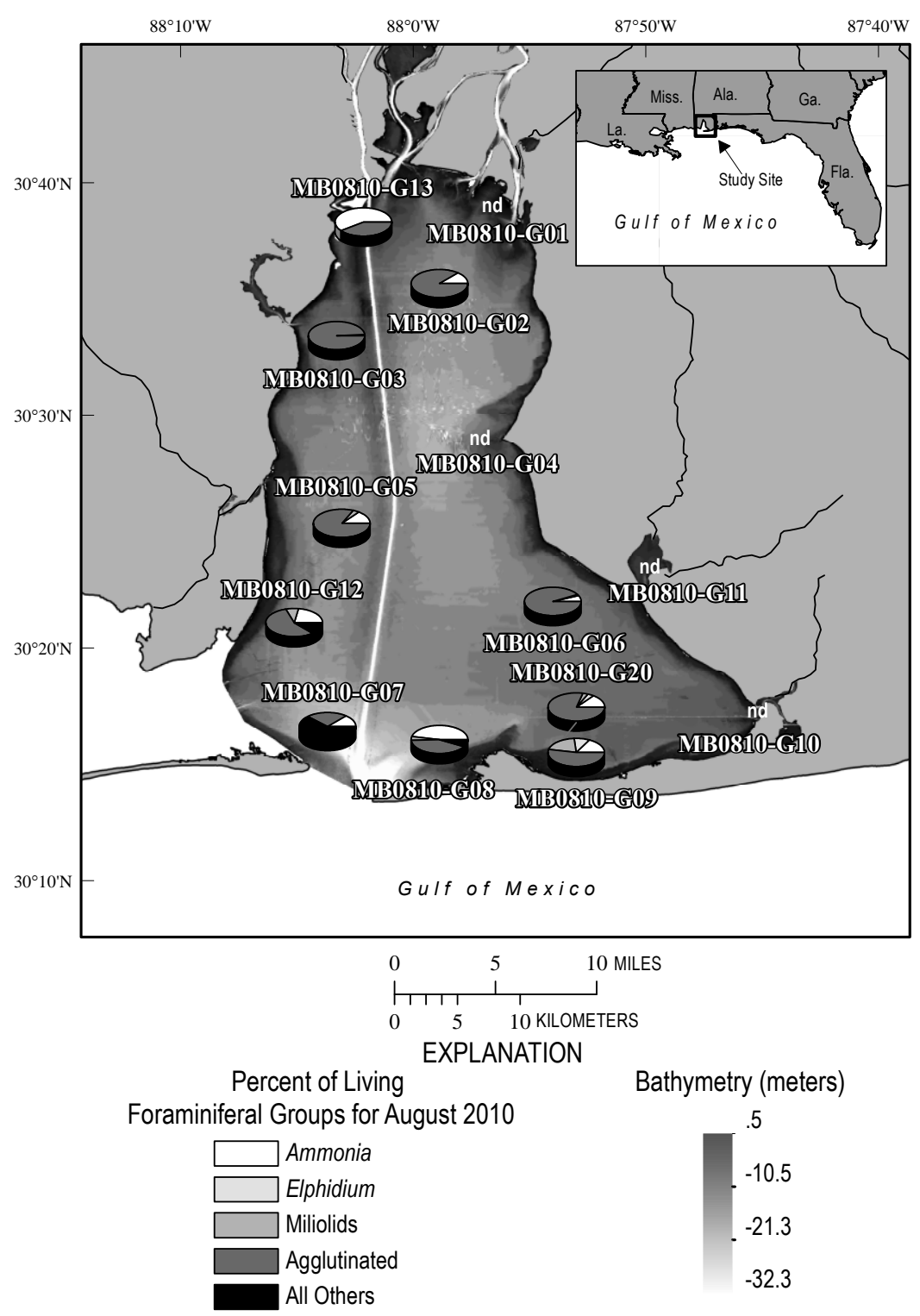

Figure 14. Pie charts showing the relative abundance of living species (stained) of each of these groups at 10 sample sites collected August $5-7,2010$ (table 4). Surface sediments were collected and saturated with a Rose Bengal and ethanol mixture to aid in differentiating "living" (stained) and "dead" (unstained) foraminifera. 


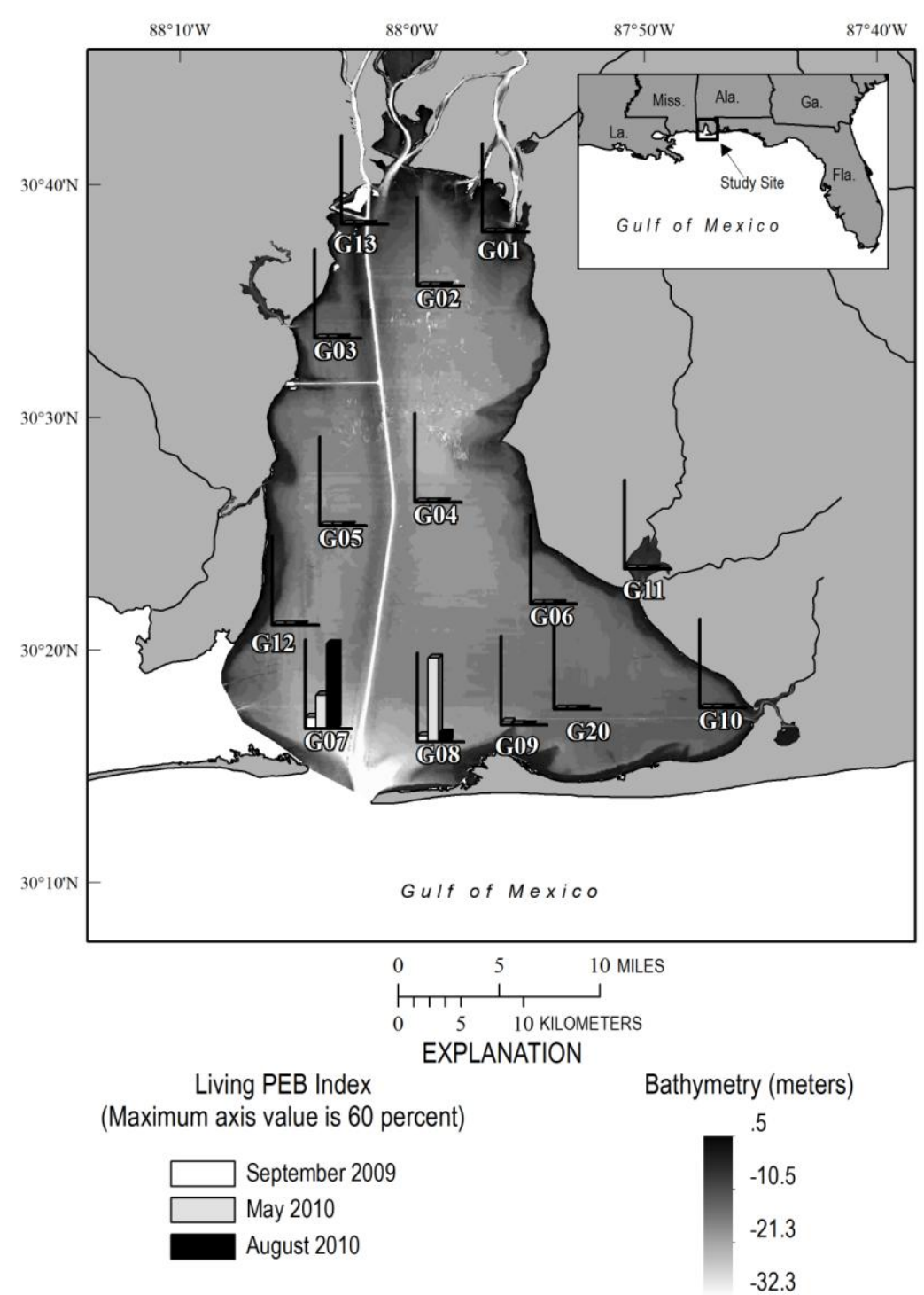

Figure 15. Column graphs showing the relative abundance of living PEB species (stained) at 14 sample sites. As a means to assess seasonal variations in water quality and its influence on the foraminiferal assemblages, the relative contribution of three calcareous foraminiferal species (the PEB index $=$ percent per Protononion atlanticum + percent per Epistominella vitrea + percent per Buliminella morgani) abundant in hypoxic areas of the Gulf of Mexico was examined. Note not all sites were collected each season (table 2). The highest stained percent of the PEB species occurs in the southernmost surface samples for several reasons. The southern sites have the deepest water and the greatest marine water exchange with the Gulf of Mexico, which allows these shelf species to live in the surface sediments in this area. Their occurrence indicates that oxygen is sometimes limited in Mobile Bay. Their absence from the remainder of the bay is probably a combination of reduced salinity and strong carbonate dissolution in Mobile Bay and should not be interpreted as lack of hypoxia in other areas on Mobile Bay (tables 2, 3,and 4). The y axis for each graph is at a maximum of 60 percent. 


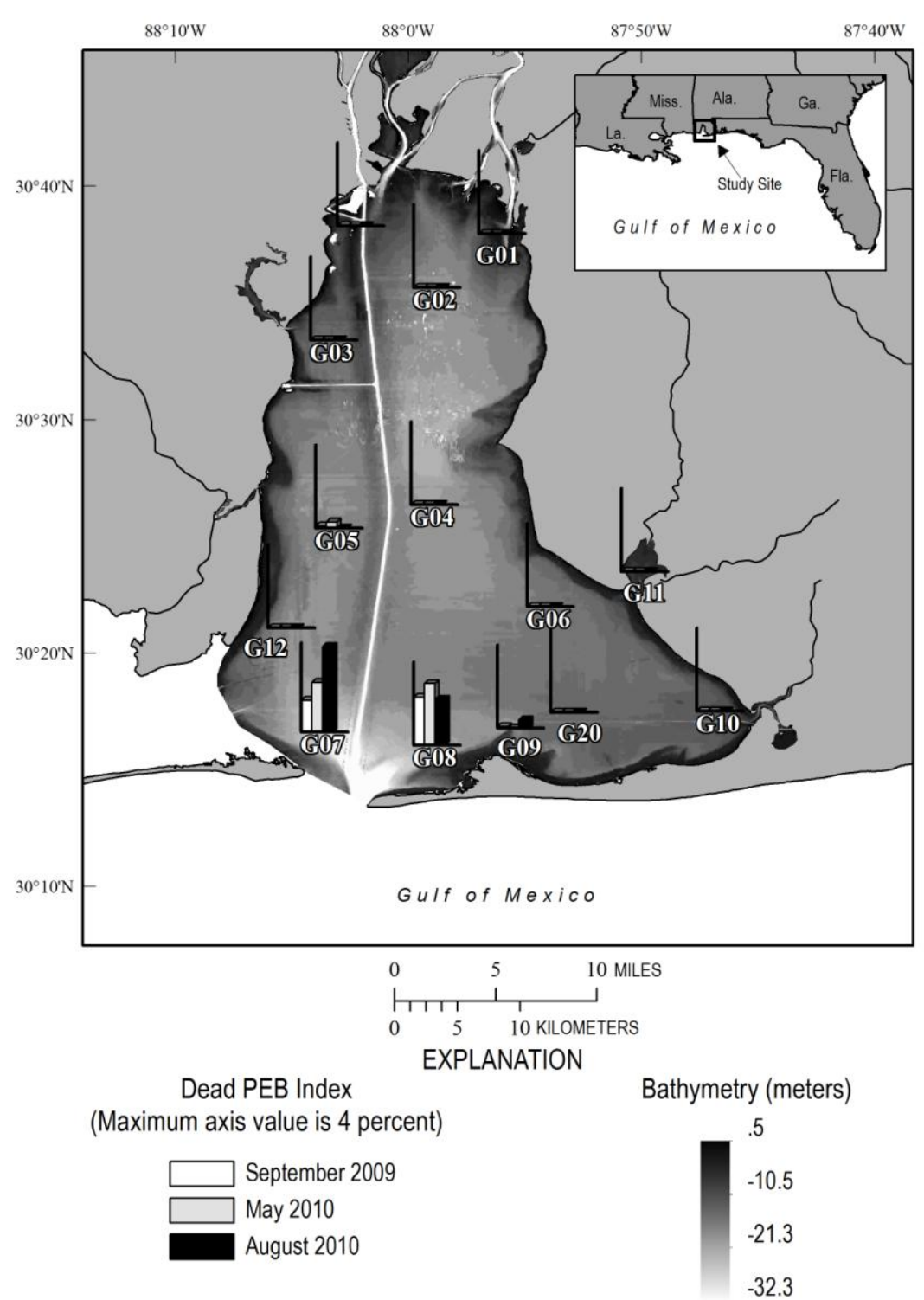

Figure 16. Column graphs showing the relative abundance of dead PEB species (unstained) at 14 sample sites. Note not all sites were collected each season (table 2). The highest stained percent of the PEB species occurs in the southernmost surface samples for several reasons. The southern sites have the deepest water and the greatest marine water exchange with the Gulf of Mexico, which allows these shelf species to live in the surface sediments in this area. Their occurrence indicates that oxygen is sometimes limited in Mobile Bay. Their absence from the remainder of the bay is probably a combination of reduced salinity and strong carbonate dissolution in Mobile Bay and should not be interpreted as lack of hypoxia in other areas on Mobile Bay (tables $2,3$,and 4$)$. The $y$ axis for each graph is at a maximum of 4 percent. 


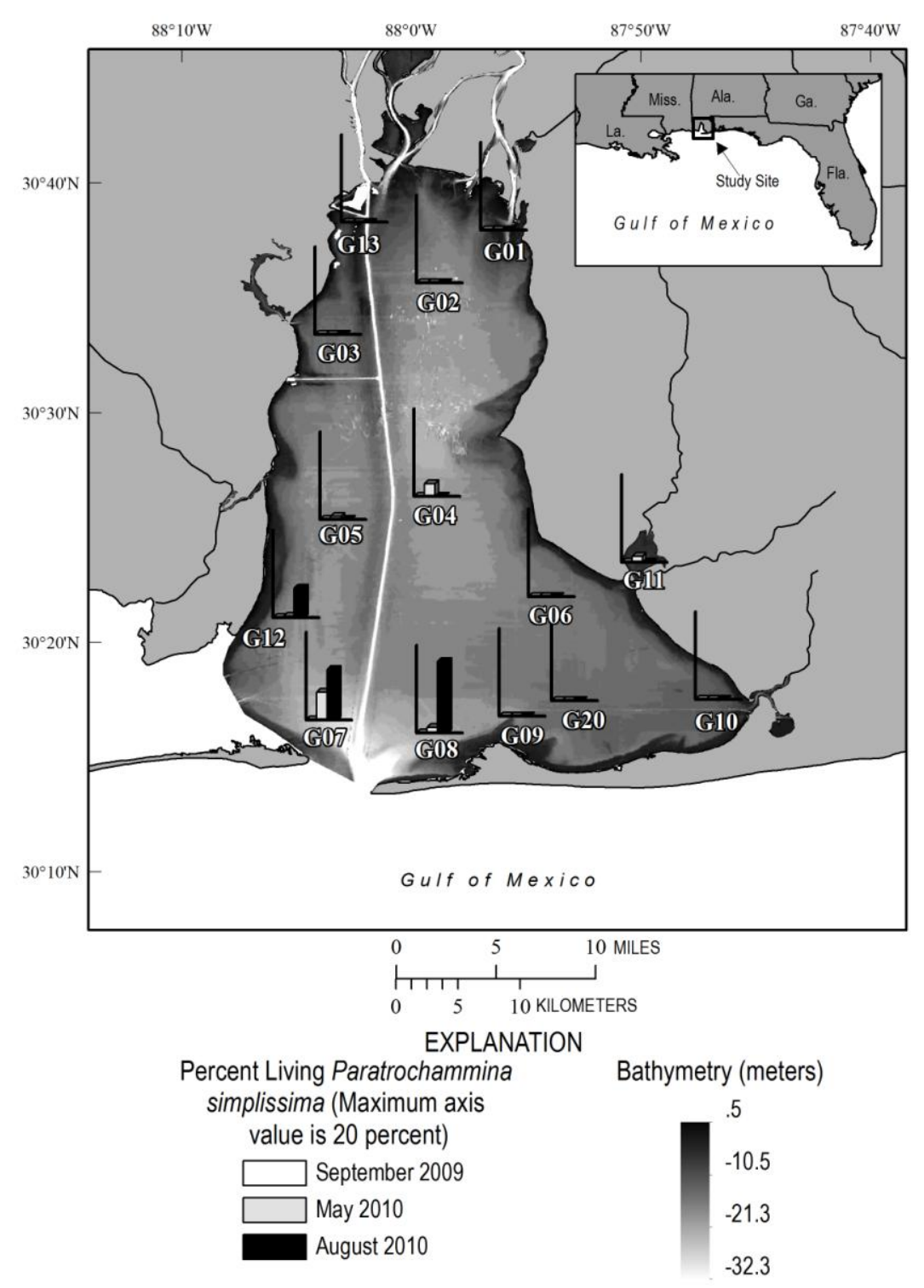

Figure 17. Column graphs showing the relative abundance of living Paratrochammina simplissima species (stained) at 14 sample sites. As a means to assess seasonal variations in water quality and its influence on an agglutinated species, the relative contribution of Paratrochammina simplissima was examined.

Paratrochammina simplissima is an agglutinated shelf species that has been recently introduced into Mobile Bay. Note not all sites were collected each season (table 2). The highest percent of stained specimens occurs in the southernmost surface samples where the PEB species indicate lowered spring and summer bottomwater oxygen (tables 2, 3,and 4). The y axis for each graph is at a maximum of 20 percent. 


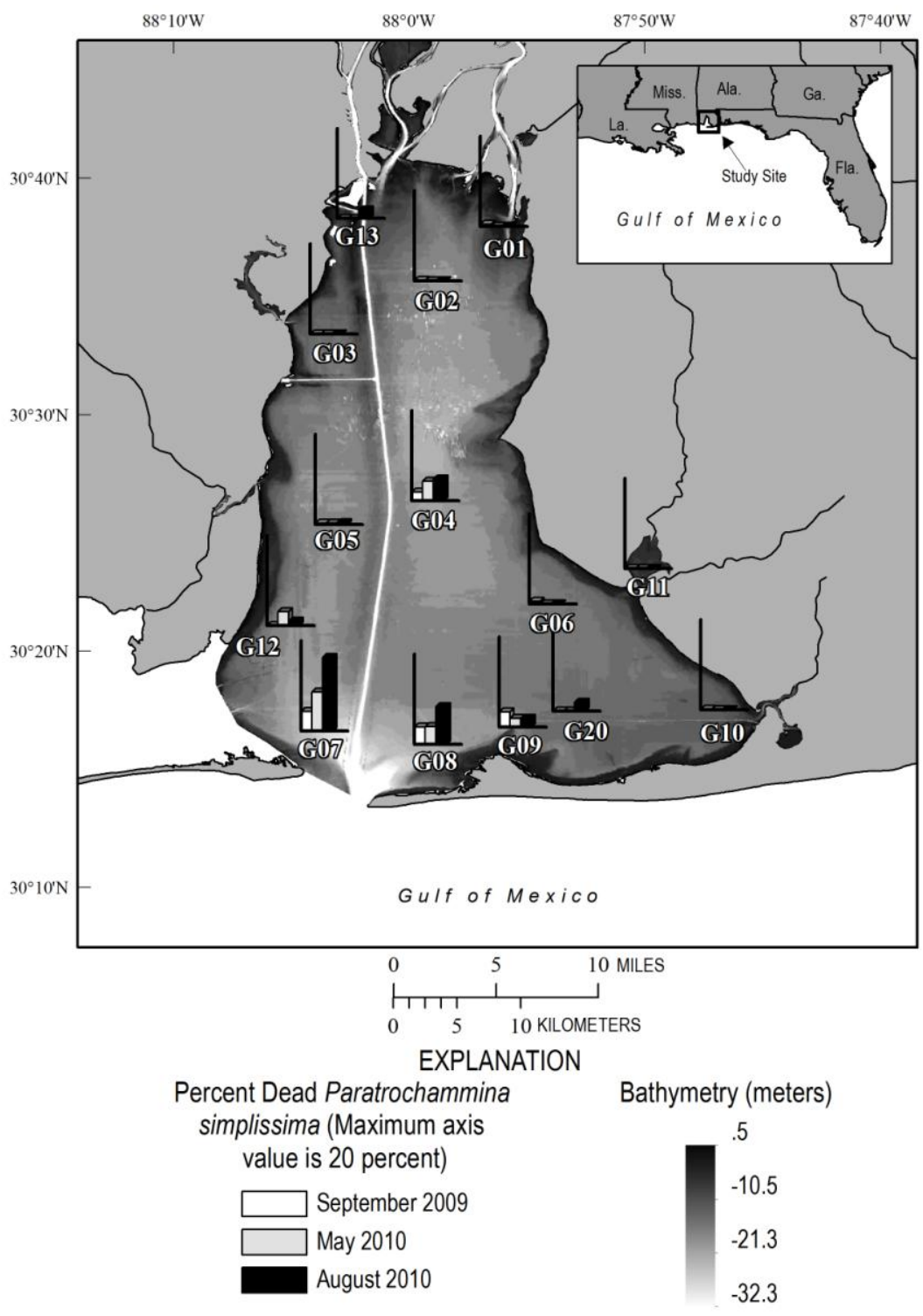

Figure 18. Column graphs showing the relative abundance of dead Paratrochammina simplissima species (unstained) at 14 sample sites. Note not all sites were collected each season (table 2). The highest percent of unstained specimens occurs in the southernmost surface samples where the PEB species indicate lowered spring and summer bottom-water oxygen (tables 2, 3,and 4). The y axis for each graph is at a maximum of 20 percent. 
Table 1. Location data table for samples collected in Mobile Bay, Alabama. [nd, not determined]

\begin{tabular}{|c|c|c|c|c|}
\hline Site Name & $\begin{array}{l}\text { Latitude }\left({ }^{\circ} \mathbf{N},\right. \\
\text { WGS84) }\end{array}$ & $\begin{array}{c}\text { Longitude }\left({ }^{\circ} \mathbf{W},\right. \\
\text { WGS84) }\end{array}$ & $\begin{array}{c}\text { Water } \\
\text { Depth } \\
\text { (meters) }\end{array}$ & $\begin{array}{c}\text { Salinity } \\
\text { (parts per } \\
\text { thousand) }\end{array}$ \\
\hline MB09-G01 & 30.655983 & 87.946587 & 1.83 & .07 \\
\hline MB09-G02 & 30.594378 & 87.981124 & 3.51 & 5.00 \\
\hline MB09-G03 & 30.557041 & 88.054864 & 3.20 & 4.10 \\
\hline MB09-G04 & 30.439431 & 87.982991 & 3.99 & 11.00 \\
\hline MB09-G05 & 30.422629 & 88.051130 & 4.08 & 5.56 \\
\hline MB09-G06 & 30.366624 & 87.899916 & 3.51 & 9.80 \\
\hline MB09-G07 & 30.277016 & 88.061398 & 5.18 & 30.77 \\
\hline MB09-G08 & 30.267682 & 87.981124 & 4.54 & 30.01 \\
\hline MB09-G09 & 30.279816 & 87.883115 & 3.17 & 9.03 \\
\hline MB09-G10 & 30.291951 & 87.778572 & 2.74 & 13.33 \\
\hline MB09-G11 & 30.391644 & 87.832330 & 1.55 & 10.36 \\
\hline MB10-G01 & 30.632483 & 87.934283 & .61 & .08 \\
\hline MB10-G02 & 30.594400 & 87.981050 & 3.35 & 2.15 \\
\hline MB10-G03 & 30.557033 & 88.054250 & 3.05 & 3.06 \\
\hline MB10-G04 & 30.439433 & 87.983017 & 4.02 & 3.42 \\
\hline MB10-G05 & 30.422633 & 88.051083 & 3.96 & 4.96 \\
\hline MB10-G06 & 30.366617 & 87.899850 & 4.88 & 4.99 \\
\hline MB10-G07 & 30.277150 & 88.061350 & 5.18 & 8.94 \\
\hline MB10-G08 & 30.267682 & 87.981124 & 4.27 & 15.04 \\
\hline MB10-G09 & 30.279883 & 87.883200 & 3.05 & 6.00 \\
\hline MB10-G10 & 30.292033 & 87.778567 & 2.44 & 5.74 \\
\hline MB10-G11 & 30.391600 & 87.832400 & 1.22 & 2.09 \\
\hline MB10-G12 & 30.352500 & 88.084650 & 3.96 & 7.76 \\
\hline MB10-G13 & 30.638450 & 88.035600 & 2.23 & 2.11 \\
\hline MB0810-G02 & 30.594400 & 87.981050 & 3.66 & 8.09 \\
\hline MB0810-G03 & 30.557033 & 88.054250 & 3.05 & 12.14 \\
\hline MB0810-G04 & 30.439433 & 87.983017 & 3.84 & 16.43 \\
\hline MB0810-G05 & 30.422610 & 88.051080 & 3.81 & 16.49 \\
\hline MB0810-G06 & 30.366617 & 87.899850 & 3.75 & 12.71 \\
\hline MB0810-G07 & 30.277190 & 88.061230 & 4.91 & 21.35 \\
\hline MB0810-G08 & 30.267650 & 87.981100 & 4.05 & 22.74 \\
\hline MB0810-G09 & 30.280050 & 87.882700 & 2.80 & 14.75 \\
\hline MB0810-G10 & 30.290690 & 87.787130 & 1.83 & 15.47 \\
\hline MB0810-G12 & 30.351440 & 88.085260 & 3.81 & 17.52 \\
\hline MB0810-G13 & 30.638460 & 88.035590 & 3.20 & 14.38 \\
\hline MB0810-G20 & 30.291000 & 87.883000 & nd & 16.45 \\
\hline
\end{tabular}


Table 2. Surface sediment data for samples collected from Mobile Bay, Alabama, in September 2009. [\%, percent; PEB, a foraminiferal index - see fig. 15 caption]

\begin{tabular}{|c|c|c|c|c|c|c|c|}
\hline Site Name & $\begin{array}{l}\text { Latitude } \\
\quad\left({ }^{\circ} \mathbf{N},\right. \\
\text { WGS84) }\end{array}$ & $\begin{array}{l}\text { Longitude } \\
\left({ }^{\circ} \mathbf{W},\right. \\
\text { WGS84) }\end{array}$ & $\begin{array}{l}\text { Collection } \\
\text { Date }\end{array}$ & $\begin{array}{c}\text { Bottom } \\
\text { Water } \\
\text { Salinity } \\
\text { (Max. 31) }\end{array}$ & $\begin{array}{l}\text { Loss-on- } \\
\text { Ignition } \\
\text { Organic } \\
\text { Matter }(\%)\end{array}$ & $\begin{array}{c}\text { Molar Total } \\
\text { Organic Carbon } \\
\text { to Total Nitrogen } \\
\text { Ratio }(\mathrm{C}: \mathrm{N})\end{array}$ & $\begin{array}{c}\text { Stable Carbon Isotopic } \\
\text { Signature, } \delta 13 C \text { (per mil) }\end{array}$ \\
\hline MB09-G01 & 30.655983 & 87.946587 & 29-Sep-09 & .07 & 2.98 & 12.06 & -28.29 \\
\hline MB09-G02 & 30.594378 & 87.981124 & 30-Sep-09 & 5.00 & 9.49 & 13.03 & -27.34 \\
\hline MB09-G03 & 30.557041 & 88.054864 & 30-Sep-09 & 4.10 & 4.90 & 11.36 & -26.68 \\
\hline MB09-G04 & 30.439431 & 87.982991 & 30-Sep-09 & 11.00 & 10.01 & 10.90 & -26.49 \\
\hline MB09-G05 & 30.422629 & 88.051130 & 30-Sep-09 & 5.56 & 8.32 & 9.93 & -25.62 \\
\hline MB09-G06 & 30.366624 & 87.899916 & 30-Sep-09 & 9.80 & 9.84 & 9.85 & -25.68 \\
\hline MB09-G07 & 30.277016 & 88.061398 & 30-Sep-09 & 30.77 & 8.38 & 10.86 & -24.19 \\
\hline MB09-G08 & 30.267682 & 87.981124 & 30-Sep-09 & 30.01 & 10.58 & 9.83 & -24.01 \\
\hline MB09-G09 & 30.279816 & 87.883115 & 30-Sep-09 & 9.03 & 9.29 & 9.76 & -24.95 \\
\hline MB09-G10 & 30.291951 & 87.778572 & 30-Sep-09 & 13.33 & 9.85 & 10.10 & -24.97 \\
\hline MB09-G11 & 30.391644 & 87.832330 & 30-Sep-09 & 10.36 & 10.37 & 12.96 & -26.37 \\
\hline
\end{tabular}

\begin{tabular}{|c|c|c|c|c|c|c|c|c|}
\hline Site Name & $\begin{array}{c}\text { Stable } \\
\text { Nitrogen } \\
\text { Isotopic } \\
\text { Signature, } \\
\boldsymbol{\delta 1 5 N} \text { (per mil) }\end{array}$ & $\begin{array}{l}\text { Stained } \\
\text { Density }\end{array}$ & $\begin{array}{c}\text { Stained \% } \\
\text { Abundance, } \\
\text { Ammonia }\end{array}$ & $\begin{array}{c}\text { Stained \% } \\
\text { Abundance, } \\
\text { Elphidium }\end{array}$ & $\begin{array}{c}\text { Stained \% } \\
\text { Abundance, } \\
\text { Miliolids }\end{array}$ & $\begin{array}{c}\text { Stained \% } \\
\text { Abundance, } \\
\text { Agglutinates }\end{array}$ & $\begin{array}{c}\text { Stained \% } \\
\text { Abundance, } \\
\text { All Others }\end{array}$ & Stained \% PEB \\
\hline MB09-G01 & 5.75 & .48 & .00 & 100.00 & .00 & .00 & .00 & .00 \\
\hline MB09-G02 & 5.06 & 1.90 & 88.00 & .00 & .00 & .00 & 12.00 & .00 \\
\hline MB09-G03 & 5.68 & 4.86 & 97.00 & 2.00 & .00 & 1.00 & .00 & .00 \\
\hline MB09-G04 & 5.42 & 1.08 & 100.00 & .00 & .00 & .00 & .00 & .00 \\
\hline MB09-G05 & 5.90 & 1.49 & 100.00 & .00 & .00 & .00 & .00 & .00 \\
\hline MB09-G06 & 5.64 & 2.37 & 94.00 & 6.00 & .00 & .00 & .00 & .00 \\
\hline MB09-G07 & 5.45 & .96 & 73.00 & 12.00 & .00 & 4.00 & .00 & 8.00 \\
\hline MB09-G08 & 6.00 & 5.61 & 77.00 & 18.00 & .00 & .00 & .00 & 4.00 \\
\hline MB09-G09 & 5.82 & 1.15 & 70.00 & 28.00 & .00 & .00 & .00 & 2.00 \\
\hline MB09-G10 & 5.44 & 2.88 & 12.00 & 88.00 & .00 & .00 & .00 & .00 \\
\hline MB09-G11 & 5.20 & 2.75 & 14.00 & 7.00 & .00 & 80.00 & .00 & .00 \\
\hline
\end{tabular}

\begin{tabular}{|c|c|c|c|c|c|c|c|c|c|}
\hline Site Name & $\begin{array}{c}\text { Stained \% } \\
P . \\
\text { simplissima }\end{array}$ & $\begin{array}{c}\text { Dead } \\
\text { Density }\end{array}$ & $\begin{array}{c}\text { Dead \% } \\
\text { Abundance, } \\
\text { Ammonia }\end{array}$ & $\begin{array}{c}\text { Dead \% } \\
\text { Abundance, } \\
\text { Elphidium }\end{array}$ & $\begin{array}{c}\text { Dead \% } \\
\text { Abundance, } \\
\text { Miliolids }\end{array}$ & $\begin{array}{c}\text { Dead \% } \\
\text { Abundance, } \\
\text { Agglutinates }\end{array}$ & $\begin{array}{c}\text { Dead \% } \\
\text { Abundance, } \\
\text { All Others }\end{array}$ & $\begin{array}{l}\text { Dead } \\
\% \text { PEB }\end{array}$ & $\begin{array}{l}\text { Dead \% P. } \\
\text { simplissima }\end{array}$ \\
\hline MB09-G01 & .00 & 100.00 & .10 & 1.20 & .00 & 99.00 & .00 & .00 & .50 \\
\hline MB09-G02 & .00 & 102.00 & 15.93 & .00 & .13 & 83.94 & .00 & .00 & .10 \\
\hline MB09-G03 & .00 & 680.00 & 12.00 & .00 & .00 & 88.00 & .00 & .00 & .00 \\
\hline MB09-G04 & .00 & 177.00 & 19.20 & 4.50 & 7.12 & 69.19 & .00 & .00 & 2.00 \\
\hline MB09-G05 & .00 & 626.00 & 12.57 & 4.58 & 4.84 & 77.88 & .13 & .10 & .30 \\
\hline MB09-G06 & .00 & 166.00 & 22.00 & 5.50 & 4.40 & 68.00 & .00 & .00 & .60 \\
\hline MB09-G07 & .00 & 101.00 & 36.15 & 12.00 & 2.88 & 43.35 & 5.40 & 1.60 & 4.50 \\
\hline MB09-G08 & .00 & 527.00 & 40.51 & 16.30 & 16.44 & 14.35 & 15.10 & 2.40 & 4.00 \\
\hline MB09-G09 & .00 & 245.00 & 23.33 & 19.70 & 7.54 & 48.41 & 2.32 & .07 & 3.50 \\
\hline MB09-G10 & .00 & 278.00 & 19.00 & 18.60 & 2.10 & 60.30 & .00 & .00 & .10 \\
\hline MB09-G11 & .00 & 91.30 & .30 & .40 & .00 & 99.30 & .00 & .00 & .00 \\
\hline
\end{tabular}


Table 3. Surface sediment data for samples collected from Mobile Bay, Alabama, in May 2010. [\%, percent; PEB, a foraminiferal index - see fig. 15 caption; nd, not determined ]

\begin{tabular}{|c|c|c|c|c|c|c|c|c|c|c|c|}
\hline Site Name & $\begin{array}{l}\text { Latitude } \\
\quad\left({ }^{\circ} \mathrm{N},\right. \\
\text { WGS84) }\end{array}$ & $\begin{array}{c}\text { Longitude } \\
\left({ }^{\circ} \mathrm{W},\right. \\
\text { WGS84) }\end{array}$ & $\begin{array}{l}\text { Collection } \\
\text { Date }\end{array}$ & \multicolumn{2}{|c|}{$\begin{array}{c}\text { Bottom } \\
\text { Water } \\
\text { Salinity } \\
\text { (Max. 31) }\end{array}$} & \multicolumn{2}{|c|}{$\begin{array}{c}\text { Loss-on- } \\
\text { Ignition } \\
\text { Organic Matter } \\
(\%)\end{array}$} & \multicolumn{2}{|c|}{$\begin{array}{l}\text { Molar Total Organic } \\
\text { Carbon to Total } \\
\text { Nitrogen Ratio }(\mathrm{C}: \mathrm{N})\end{array}$} & \multicolumn{2}{|c|}{$\begin{array}{l}\text { Stable Carbon } \\
\text { Isotopic } \\
\text { Signature, } \\
\delta 13 C \text { (per mil) }\end{array}$} \\
\hline MB10-G01 & 30.632483 & 87.934283 & 21-May-10 & \multicolumn{2}{|c|}{0.08} & \multicolumn{3}{|c|}{4.73} & \multicolumn{2}{|c|}{9.71} & -27.80 \\
\hline MB10-G02 & 30.594400 & 87.981050 & 21-May-10 & \multicolumn{2}{|c|}{2.15} & \multicolumn{2}{|r|}{6.81} & & \multicolumn{2}{|c|}{7.81} & -27.37 \\
\hline MB10-G03 & 30.557033 & 88.054250 & 21-May-10 & \multicolumn{2}{|c|}{3.06} & \multicolumn{2}{|r|}{5.81} & & \multicolumn{2}{|c|}{8.61} & -26.71 \\
\hline MB10-G04 & 30.439433 & 87.983017 & 21-May-10 & \multicolumn{2}{|c|}{3.42} & \multicolumn{2}{|r|}{9.19} & & \multicolumn{2}{|c|}{ nd } & nd \\
\hline MB10-G05 & 30.422633 & 88.051083 & 21-May-10 & & 4.96 & & 8.73 & & & 3.27 & -26.68 \\
\hline MB10-G06 & 30.366617 & 87.899850 & 20-Мay-10 & & 4.99 & & 9.67 & & & 7.05 & -25.86 \\
\hline MB10-G07 & 30.277150 & 88.061350 & 20-May-10 & & 8.94 & & 8.35 & & & .40 & -24.27 \\
\hline MB10-G08 & 30.267682 & 87.981124 & 20-Мay-10 & & 5.04 & & 10.81 & & & 3.56 & -24.90 \\
\hline MB10-G09 & 30.279883 & 87.883200 & 20-May-10 & & 6.00 & & 10.33 & & & 1.24 & -25.17 \\
\hline MB10-G10 & 30.292033 & 87.778567 & 20-May-10 & & 5.74 & & 7.50 & & & 3.08 & -24.80 \\
\hline MB10-G11 & 30.391600 & 87.832400 & 20-Мay-10 & & 2.09 & & 9.09 & & & .27 & -25.63 \\
\hline MB10-G12 & 30.352500 & 88.084650 & 20-May-10 & & 7.80 & & 9.44 & & & .77 & -24.97 \\
\hline MB10-G13 & 30.638450 & 88.035600 & 21-May-12 & & 2.11 & & 4.65 & & 12. & .01 & -26.10 \\
\hline Site Name & $\begin{array}{c}\text { Stable } \\
\text { Nitrogen } \\
\text { Isotopic } \\
\text { Signature, } \\
\text { } 15 \mathrm{~N} \text { (per mil) } \\
\end{array}$ & $\begin{array}{l}\text { Stained } \\
\text { Density }\end{array}$ & $\begin{array}{c}\text { Stained \% } \\
\text { Abundance, } \\
\text { Ammonia }\end{array}$ & $\begin{array}{l}\text { ined \% } \\
\text { indance, } \\
\text { hidium }\end{array}$ & $\begin{array}{r}\mathrm{St} \\
\mathrm{Ab} \\
N\end{array}$ & $\begin{array}{l}\text { tained \% } \\
\text { bundance, } \\
\text { Miliolids }\end{array}$ & $\begin{array}{l}\text { Stain } \\
\text { Abund } \\
\text { Agglut }\end{array}$ & $\begin{array}{l}\text { ed \% } \\
\text { lance, } \\
\text { inates }\end{array}$ & $\begin{array}{c}\text { Stained \% } \\
\text { Abundance, } \\
\text { All Others }\end{array}$ & Sta & ed \% PEB \\
\hline MB10-G01 & 0.00 & nd & nd & nd & & nd & & nd & nd & & nd \\
\hline MB10-G02 & 0.00 & 24.00 & 11.11 & 0.48 & & 0.00 & & 88.40 & 0.00 & & 0.00 \\
\hline MB10-G03 & 0.00 & 341.00 & 5.00 & 0.00 & & 0.00 & & 95.00 & 0.00 & & 0.00 \\
\hline MB10-G04 & 3.00 & 76.00 & 26.89 & 12.34 & & 9.80 & & 51.00 & 0.00 & & 0.00 \\
\hline MB10-G05 & 0.70 & 168.00 & 24.54 & 6.13 & & 2.15 & & 66.87 & 0.30 & & 0.30 \\
\hline MB10-G06 & 0.00 & nd & nd & nd & & nd & & nd & nd & & nd \\
\hline MB10-G07 & 6.60 & 30.70 & 53.73 & 16.77 & & 1.24 & & 22.36 & 5.97 & & 2.50 \\
\hline MB10-G08 & 1.30 & 66.70 & 38.85 & 18.15 & & 11.10 & & 16.88 & 15.00 & & 3.10 \\
\hline MB10-G09 & 0.00 & 47.00 & 29.00 & 27.00 & & 5.00 & & 39.00 & 0.00 & & 0.00 \\
\hline MB10-G10 & 0.00 & nd & nd & nd & & nd & & nd & nd & & nd \\
\hline MB10-G11 & 1.40 & nd & nd & nd & & nd & & nd & nd & & nd \\
\hline MB10-G12 & 0.30 & 94.00 & 49.21 & 22.90 & & 1.59 & & 26.30 & 0.00 & & 0.00 \\
\hline MB10-G13 & 0.00 & nd & nd & nd & & nd & & nd & nd & & nd \\
\hline Site Name & $\begin{array}{c}\text { Stained \% } \\
P . \\
\text { simplissima }\end{array}$ & $\begin{array}{c}\text { Dead } \\
\text { Density }\end{array}$ & $\begin{array}{c}\text { Dead \% } \\
\text { Abundance, } \\
\text { Ammonia }\end{array}$ & $\begin{array}{l}\text { Id \% } \\
\text { dance, } \\
\text { idium }\end{array}$ & $\begin{array}{r}\text { De } \\
\text { Abu } \\
\text { Mi }\end{array}$ & $\begin{array}{l}\text { ead \% } \\
\text { Indance, } \\
\text { iliolids }\end{array}$ & $\begin{array}{c}\text { Dead } \\
\text { Abunda } \\
\text { Agglutin }\end{array}$ & $\begin{array}{l}\% \\
\text { nce, } \\
\text { lates }\end{array}$ & $\begin{array}{c}\text { Dead \% } \\
\text { Abundance, } \\
\text { All Others }\end{array}$ & $\begin{array}{c}\text { Dead } \\
\% \text { PEB }\end{array}$ & $\begin{array}{l}\text { Dead } \% P . \\
\text { simplissima }\end{array}$ \\
\hline MB10-G01 & 4.85 & 0.00 & 0.00 & 0.00 & & 0.00 & & 0.00 & 0.00 & 0.00 & 4.85 \\
\hline MB10-G02 & 3.21 & 4.80 & 20.00 & 1.00 & & 0.00 & & 9.00 & 0.00 & 0.00 & 3.21 \\
\hline MB10-G03 & 4.42 & 47.80 & 4.00 & 0.40 & & 0.00 & & 6.00 & 0.00 & 0.00 & 4.42 \\
\hline MB10-G04 & nd & 3.40 & 46.00 & 0.00 & & 0.80 & & 3.00 & 0.20 & 0.00 & nd \\
\hline MB10-G05 & 4.19 & 19.00 & 10.00 & 0.20 & & 0.20 & & 0.00 & 0.00 & 0.00 & 4.19 \\
\hline MB10-G06 & 4.56 & 12.50 & 11.50 & 1.70 & & 0.20 & & 6.60 & 0.00 & 0.00 & 4.56 \\
\hline MB10-G07 & 5.57 & 33.30 & 6.70 & 0.30 & & 0.70 & & 8.00 & 24.50 & 23.60 & 5.57 \\
\hline MB10-G08 & 5.83 & 6.50 & 12.20 & 9.00 & & 4.00 & & 1.50 & 63.00 & 59.00 & 5.83 \\
\hline MB10-G09 & 3.17 & 7.60 & 3.20 & 22.00 & & 0.80 & & 4.00 & 0.40 & 0.40 & 3.17 \\
\hline MB10-G10 & 5.33 & 10.10 & 35.00 & 9.20 & & 1.30 & & 5.00 & 0.00 & 0.00 & 5.33 \\
\hline MB10-G11 & 3.36 & 2.70 & 0.00 & 10.00 & & 0.00 & & 0.00 & 0.00 & 0.00 & 3.36 \\
\hline MB10-G12 & 6.12 & 31.00 & 55.00 & 0.09 & & 0.30 & & 4.00 & 0.00 & 0.00 & 6.12 \\
\hline MB10-G13 & 4.17 & 9.00 & 1.20 & 0.40 & & 0.00 & & 8.00 & 0.00 & 0.00 & 4.17 \\
\hline
\end{tabular}


Table 4. Surface sediment data for samples collected from Mobile Bay, Alabama, in August 2010. [\%, percent; PEB, a foraminiferal index - see fig. 15 caption; nd, not determined]

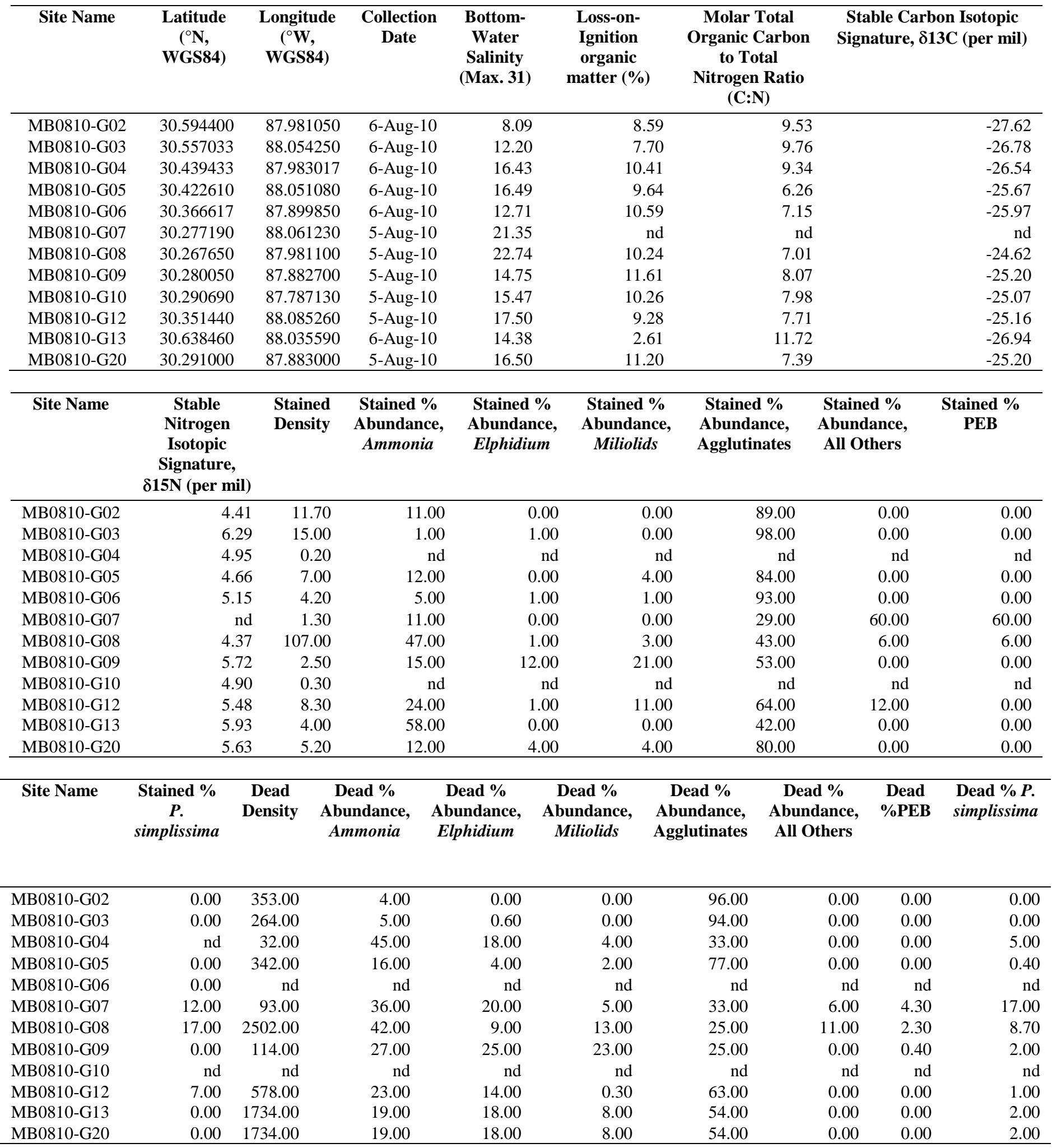

